\title{
Governismo local: relação Executivo-Legislativo em municípios do estado de Minas Gerais
}

\author{
Marta Mendes da Rocha ${ }^{1}$ (D)
}

\begin{abstract}
Este artigo investiga a extensão do governismo no nível municipal, os incentivos para o alinhamento ao Executivo e as estratégias utilizadas pelos prefeitos para construir sua base de apoio na câmara municipal. A análise se baseou em dados de um survey inédito realizado em uma amostra de vereadores de municípios de Minas Gerais. As evidências mostram que o governismo é menos disseminado do que se poderia supor e que há espaço para uma ação independente dos vereadores. Também revelam que há uma parcela importante de vereadores disposta a permanecer na oposição e a mobilizar mecanismos de fiscalização e controle do Executivo. O artigo contribui para lançar luzes a respeito de um aspecto ainda pouco explorado pela literatura sobre o tema e problematiza a ideia do governismo generalizado no nível municipal e da completa subordinação das câmaras municipais aos prefeitos.

Palavras-chave: prefeito; vereador; câmara municipal; governismo; fiscalização
\end{abstract}

\section{Introdução}

A Constituição brasileira promulgada em 1988 consagrou o federalismo com três níveis de governo, a autonomia dos municípios e a reprodução do presidencialismo com separação de poderes nas três esferas. Assim como ocorre nos níveis nacional e estadual, nos municípios, os cidadãos contam com dois representantes: o prefeito, no Poder Executivo, e os vereadores, que compõem as câmaras municipais, no Legislativo. Prefeitos e vereadores são eleitos na mesma ocasião, em eleições separadas das nacionais e estaduais, para um mandato de quatro anos. Como é típico do presidencialismo, seus mandatos têm origem separada e sua sobrevivência no cargo, pelo menos em tese, é independente do apoio e do alinhamento mútuos. Mas, como ocorre nas demais esferas de governo, os prefeitos necessitam do apoio de uma maioria no Legislativo para aprovar seus projetos.

Estudos sobre as relações Executivo-Legislativo no Brasil chamam a atenção para a centralidade do primeiro como ator decisório, nas três esferas (Figueiredo e Limongi,

\footnotetext{
1 Universidade Federal de Juiz de Fora, Departamento de Ciências Sociais, Instituto de Ciências Humanas. Juiz de Fora (MG), Brasil. E-mail: <mendes_rocha@yahoo.com.br>.
} 
1999; Abrúcio, 1998; Lopez, 2004). Essa centralidade já foi caracterizada como abdicação dos legisladores de exercerem a contento suas funções e/ou como usurpação das prerrogativas decisórias dos parlamentares por parte do Executivo, levando a um quadro de cooptação e subordinação do Legislativo (O'Donnell, 1994; Abrúcio, 1998). Em outra chave, já foi descrita como resultado de uma delegação voluntária e racional de responsabilidades dos legisladores para a esfera do Executivo com benefícios de lado a lado (Carey e Shugart, 1998). Vários estudos sobre o processo decisório municipal caracterizam as relações entre prefeito e vereadores na chave da abdicação e da subordinação/cooptação, apresentando as câmaras municipais como instituições frágeis e os vereadores como atores políticos esvaziados de prerrogativas decisórias e orientados para ações assistencialistas de menor importância e com baixo impacto sobre a vida dos cidadãos (Andrade, 1998; Lopez, 2004; Grin, 2012). Os prefeitos aparecem como figuras de relevo no nível municipal, dadas as suas prerrogativas e seus recursos institucionais. O resultado seria o predomínio do governismo, entendido como uma tendência de os vereadores se alinharem ao prefeito e aprovarem, sem mais, suas iniciativas, negligenciando sua função de fiscalização e fazendo vistas grossas para irregularidades cometidas no âmbito da administração municipal.

Esse quadro é explicado ora pelas características do desenho institucional que reserva aos prefeitos a maior parte das prerrogativas decisórias e amplia sobremaneira os custos para a aprovação de projetos de lei de autoria dos vereadores (Rocha e Silva, 2017); ora por uma suposta cultura política assistencialista difundida entre os vereadores e entre os eleitores (Grin, 2012); outras vezes, a explicação se baseia nas fragilidades institucionais que caracterizam a grande maioria das câmaras municipais no Brasil (Andrade, 1998). Essas conclusões, no entanto, em boa medida, resultam de estudos de caso que não fornecem subsídios para afirmações mais abrangentes sobre as relações entre vereadores e prefeitos no Brasil. Embora, de fato, tudo leve a apostar na disseminação do governismo entre os vereadores, a diversidade do contexto e das condições nas quais se exerce a representação nos milhares de municípios do país nos obriga a transformar em problema de pesquisa o que, para muitos, aparece como premissa. Logo, a primeira questão que pretendemos enfrentar neste artigo é: quão disseminado é o governismo no nível municipal?

Buscamos passar em revista algumas noções e ideias difundidas na literatura acadêmica, no campo midiático e entre os cidadãos sobre as relações entre prefeitos e vereadores. E oferecer respostas, ainda que parciais, a algumas questões como: É possível falar em predomínio do governismo no nível municipal? Em caso positivo, como ele se manifesta? A reprodução do presidencialismo com separação de poderes nos municípios tem implicações práticas na dinâmica de interação entre os poderes ou não passa de mera formalidade? Os vereadores, de fato, abdicam da tarefa de fiscalizar o Executivo? Por meio de que mecanismos e estratégias e com quais recursos os prefeitos buscam o apoio dos vereadores? 
Nossa hipótese inicial era que o governismo seria menos disseminado do que o sugerido pela literatura e que sua presença seria mais marcante nos municípios menos populosos nos quais tanto os cidadãos quanto os vereadores são mais dependentes dos recursos públicos e, por isso, sofrem uma pressão mais forte para manter boas relações com o prefeito. Além disso, nos municípios menores, devido ao fato de as câmaras municipais, em geral, contarem com menor grau de desenvolvimento institucional, a instituição e seus membros encontrariam condições menos favoráveis para uma postura independente ou de oposição ao prefeito. Nos demais cenários, nossa aposta era que teríamos um quadro mais diverso no que se refere às relações entre Executivo e Legislativo em função das particularidades da competição política local.

Neste artigo investigamos essas questões a partir de um conjunto inédito de dados de opinião obtidos junto a 422 vereadores de 44 municípios do estado de Minas Gerais, eleitos em 2012 para a legislatura 2013-2016 (Nepol/PPGCSO/UFJF, 2015)². O survey foi conduzido de fevereiro a novembro de 2015 em municípios de diferentes portes populacionais e níveis de desenvolvimento, o que nos oferece a oportunidade de abordar o problema do governismo em distintos cenários. Não se trata de uma amostra representativa dos municípios e/ou dos vereadores do estado e do país, logo, nossas afirmações não podem ser generalizadas para o universo. No entanto, o perfil dos vereadores da amostra guarda muitas semelhanças com o perfil dos vereadores eleitos no estado e no país no ano de 2012. Em face do estágio atual dos estudos sobre as relações entre Executivo e Legislativo no nível municipal, neste artigo, priorizamos uma análise exploratória e descritiva dos dados.

O artigo está organizado em três seções, além desta "Introdução". Na primeira, "Governismo no nível municipal: o que diz a literatura", apresentamos uma breve discussão da literatura acadêmica sobre as relações entre Executivo e Legislativo no nível municipal no Brasil. Na segunda, "Relações entre prefeitos e vereadores em Minas Gerais", dividida em seis subseções, expomos e discutimos os resultados da análise descritiva dos dados. Finalizando, na quarta seção, apresentamos as "Considerações finais".

\section{Governismo no nível municipal: o que diz a literatura}

Os estudos sobre as relações Executivo-Legislativo no nível municipal no Brasil são bem mais escassos quando comparados com as pesquisas nos níveis estadual e nacional. Desde a promulgação da nova Constituição, vemos, contudo, um interesse crescente em compreender a dinâmica de relacionamento entre prefeitos e vereadores, considerando o fortalecimento dos municípios e sua importância na execução de políticas

\footnotetext{
2 Pesquisa financiada pela Fundação de Amparo à Pesquisa de Minas Gerais (Fapemig-APQ-01978-13 e APQ-02167-15). A base de dados dessa pesquisa está disponível no site do Cesop, em Revista Opinião Pública, ao final da página do artigo (<https://www.cesop.unicamp.br/por/opiniao_publica/artigo/682>).
} 
sociais fundamentais para os cidadãos. A maior parte dos estudos sobre o tema consiste em estudos de caso cujas conclusões dificilmente poderiam ser generalizadas para o conjunto dos municípios (Andrade, 1998; Caetano, 2004; Garcia, 2013; D’Ávila Filho, Lima e Jorge, 2014; Barbosa, 2015). Em face desse quadro, podemos dizer que sabemos ainda pouco sobre os padrões de interação entre prefeitos e vereadores no país.

Uma ideia bastante disseminada é que, no nível local, o prefeito é o principal ator político, seja devido às suas prerrogativas decisórias e ao conjunto dos recursos que controla, seja em função da fragilidade institucional das câmaras municipais (Andrade, 1998). A distribuição de competências entre Executivo e Legislativo no nível municipal remonta à Constituição de 1988, que prevê que as câmaras municipais são responsáveis pela fiscalização do município via controle externo, com o auxílio dos Tribunais de Contas dos estados, e pela aprovação das contas dos prefeitos. A Constituição também estabelece que as leis orgânicas municipais - que devem ser aprovadas por dois terços dos membros da câmara municipal - devem organizar as funções legislativas e fiscalizadoras da câmara. Cabe ao Legislativo municipal a prerrogativa exclusiva de definir os vencimentos de prefeitos e vereadores, o direito de apresentar matérias sobre tributos, alterar o orçamento, propor alterações em projetos de lei iniciados pelo prefeito, legislar sobre áreas importantes como saúde, educação e uso de solo, além de elaborar os planos diretores dos municípios (Silva, 2014).

Mas o conhecimento preciso da distribuição das competências entre os poderes dependeria de uma análise das 26 Constituições estaduais e das leis orgânicas municipais. Isso porque a Constituição não detalha as competências dos prefeitos. $O$ que sabemos é que as Constituições estaduais, aprovadas em 1989, um ano após a promulgação da Constituição Federal, reproduziram, em grande medida, os princípios e as regras fixadas na carta maior (Couto e Absher-Bellon, 2018). O mesmo mimetismo seria observado no nível municipal. Os Tribunais de Justiça que realizam o controle abstrato das leis estaduais e municipais tomam as Constituições estaduais como parâmetro e, por consequência, os prefeitos têm sido contemplados com prerrogativas semelhantes às dos chefes do Executivo nas outras esferas - iniciativa exclusiva em certas áreas, monopólio na elaboração do projeto de lei orçamentária, veto total e parcial, entre outros ${ }^{3}$. Como resultado, o prefeito seria dotado de importantes poderes decisórios e os vereadores encontrariam muitas restrições para exercer sua função legisladora.

A combinação de um prefeito forte e uma câmara municipal e vereadores frágeis ${ }^{4}$ levaria a uma franca assimetria entre os poderes, desequilíbrio que explicaria a tendência das câmaras e dos vereadores ao governismo. Tomando o governismo como um fato, a

\footnotetext{
3 Agradeço a Bruno Souza da Silva pelos comentários a respeito do controle abstrato das leis estaduais e municipais pelos Tribunais de Justiça.

4 Para uma análise pormenorizada do grau de profissionalização das câmaras municipais brasileiras ver Silva (2014).
} 
questão que ocupa boa parte dos estudiosos do tema é entender como o prefeito busca conquistar e manter o apoio e a lealdade dos vereadores (Praça e Garcia, 2011; Garcia, 2013; Grin, 2012). Em linhas gerais e de forma esquemática, a literatura considera as seguintes possibilidades: (1) o prefeito prioriza a negociação com os vereadores individualmente versus o prefeito prioriza a negociação com o bloco de vereadores, se valendo da mediação das lideranças partidárias; (2) a negociação envolve concessão de cargos na administração municipal em troca do voto favorável dos vereadores na câmara, com mediação das lideranças partidárias versus a negociação envolve o atendimento de demandas particulares dos vereadores, sem coordenação partidária; (3) as negociações entre prefeitos e vereadores ocorrem antes da eleição, já na montagem das chapas, para usar um termo nativo, versus as negociações ocorrem, sobretudo, após a definição do resultado das eleições, na formação da coalizão de apoio ao prefeito, com a incorporação de novos atores à base. Não há razões para crer que as alternativas acima sejam, de fato, excludentes. Um mesmo prefeito, em uma mesma administração, pode diversificar suas estratégias e recursos, e pode, eventualmente, combiná-los.

Uma visão convergente sobre a relação entre Executivo e Legislativo pode ser encontrada nos trabalhos de Kuschnir (2000) e Lopez (2004). Os autores destacam a importância da atuação cotidiana dos vereadores e do conjunto de expectativas compartilhadas entre os eleitores para compreender as relações entre os poderes no nível local. Lopez (2004), analisando as relações entre Executivo e Legislativo em um município do interior do Rio de Janeiro, afirma que os vereadores estão constantemente em face de uma escolha: apoiar o prefeito e fazer vistas grossas para as irregularidades cometidas no âmbito da administração municipal e, assim, garantir seu acesso aos recursos públicos; ou se opor ao prefeito e enfrentar enormes dificuldades no atendimento aos eleitores. O autor mostra que as duas atividades canônicas do Legislativo - legislar e fiscalizar - não são valorizadas pelos eleitores e, por essa razão, os vereadores priorizam outras atividades com maior potencial de retorno eleitoral, a saber, o atendimento às demandas individuais e de grupos. Mas, como não possuem autoridade para tomar as providências esperadas pelos eleitores, os legisladores encontram-se em uma posição de dependência e subordinação ao prefeito. $O$ autor encontra evidências de que 0 acesso às autoridades do Executivo, bem como 0 atendimento das demandas apresentadas, decorre do grau de apoio e proximidade do vereador em relação ao prefeito. Este, ciente desse conjunto de incentivos, utilizaria o atendimento às demandas como moeda de troca fundamental na manutenção de apoio na câmara. Essa dinâmica estaria baseada nas assimetrias entre os poderes no que concerne ao grau de acesso aos recursos públicos.

Conclusões semelhantes são apresentadas por Kuschnir (2000) em seus estudos sobre a política no Rio de Janeiro. A autora, igualmente, destaca o papel de mediador do vereador entre os eleitores e suas demandas, de um lado, e o Poder Executivo, de outro. 
Papel que impõe altos custos para os que se opõem ao prefeito ou facilita o acesso e garante prioridade aos que se mostram leais.

Em outro estudo realizado por meio de entrevistas com 37 vereadores de quatro municípios do estado de Minas Gerais, Almeida e Lopez (2011) concluem pela subordinação do Legislativo ao Executivo, afirmando que: "Em geral, o prefeito domina a agenda legislativa. Os vereadores, por sua vez, entendem que apoiar o prefeito é importante para as atividades cotidianas daqueles, principalmente devido à necessidade de atendimento dos pedidos dos cidadãos" (p. 34). Neto (2003), investigando as relações Executivo-Legislativo em municípios do Vale do Paraíba de São Paulo, chega a uma conclusão semelhante: os vereadores se dedicam, principalmente, à intermediação de interesses particulares e ao atendimento de seus pedidos dos vereadores. Como dependem do prefeito para atender às demandas, os representantes abrem mão de suas prerrogativas formais de legislar e fiscalizar.

Boa parte da literatura compreende as relações entre Executivo e Legislativo na chave da cooptação e da subordinação dos vereadores, que seria possível graças à combinação de um desenho institucional que concentra poderes e recursos nas mãos do prefeito com uma cultura política que valoriza o "atendimento" em detrimento de uma ação mais programática no âmbito das políticas públicas. Nessa interpretação, os partidos políticos não desempenham papel importante na orientação do comportamento dos eleitores e dos vereadores ou em termos de coordenação política. A construção e a manutenção do apoio se dão em termos individuais ou, no máximo, a partir da configuração em grupos políticos e facções. Segundo Lopez (2004), "não há espaço para políticos orientados em termos ideológicos, se por isso entendemos um comportamento orientado por linhas estabelecidas nos programas dos partidos políticos" (p. 166)5. Ou, em outras palavras, "esse padrão de relacionamento, por sua vez, prescinde de partidos políticos para estruturá-lo" (Almeida e Lopez, 2011, p. 33-34).

Outra estratégia para investigar a relação entre Executivo e Legislativo é a análise da produção legislativa no nível municipal. No que se refere especificamente às câmaras municipais, os estudos de caso apresentam conclusões divergentes. Enquanto alguns destacam um padrão semelhante ao que se observa no nível nacional, com os parlamentares priorizando proposições de impacto difuso na área social (Caetano, 2004, 2005; Silva, 2014), outros destacam a irrelevância da maior parte da produção legislativa dos vereadores (Transparência Brasil, 2008; Gomes, 2009; Ermacovitch, 2010). Segundo alguns autores, os constrangimentos constitucionais, combinados aos altos custos para aprovar um projeto de lei, ajudariam a explicar por que os vereadores relegam a função legislativa a um segundo plano e se concentram em outras atividades

\footnotetext{
${ }^{5}$ Em outro artigo, o autor relativiza esse ponto de vista, propondo ser possível encontrar outros padrões de comportamento entre os vereadores para além do que Lopez e Almeida (2017) denominam "assistencialista".
} 
com menor impacto sobre o status quo, mas com maior visibilidade junto aos eleitores e maiores retornos eleitorais (D'Ávila Filho et al., 2004).

Barbosa (2015), analisando a aprovação de projetos de lei em Salvador no período de 2001 a 2012, encontra taxas de sucesso do Executivo próximas das observadas no nível nacional, embora as taxas de dominância estejam bem abaixo das registradas para os (as) presidentes. Conclusões semelhantes são apresentadas por Caetano (2005) e Garcia (2013) no que se refere à alta capacidade do Executivo para aprovar projetos de sua iniciativa. Os autores também destacam que, embora nem sempre a produção legislativa seja caracterizada pela dominância do Executivo, é importante considerar o aspecto qualitativo das leis. Em outras palavras, os prefeitos podem não dominar a produção legislativa, mas têm maior capacidade para aprovar projetos com impacto sobre o status quo.

Embora esses estudos não tenham como foco as relações entre os poderes, suas conclusões auxiliam a compreender o papel das câmaras e dos vereadores e o grau de assimetria entre Executivo e Legislativo. Se concluímos que os vereadores se ocupam, prioritariamente, de projetos de lei particularistas e com baixo impacto, temos fortalecida a tese de que é o Executivo o responsável pela legislação relevante e de abrangência municipal. Ainda assim, seria necessário analisar as outras formas pelas quais os vereadores podem se fortalecer na barganha com o Executivo, como a apresentação de emendas às proposições de autoria do prefeito e os mecanismos informais de atendimento aos eleitores.

Por vias diversas, diferentes estudiosos da dinâmica política e do processo decisório no município convergem na conclusão de que os vereadores se ocupam, sobretudo, de atividades voltadas para o atendimento dos eleitores, atividades que alguns classificam como assistencialismo, clientelismo e paroquialismo, designações utilizadas para indicar a entrega de benefícios particulares como forma de manter o apoio e a lealdade dos eleitores (Lopez, 2004; Grin, 2012). Uma visão diferente é oferecida por Silva (2014) em um estudo que, segundo o próprio autor, é "o maior esforço já realizado de coleta e sistematização de dados sobre projetos de lei municipais" (p. 62)6. O autor reconhece que a maioria das câmaras municipais é pouco profissionalizada e carece de estrutura física e humana, mas problematiza a tese de sua ineficiência ao mostrar que os vereadores iniciam uma vasta quantidade de matérias de relevo "tanto em áreas regulamentadas pelos demais níveis de governo (como saúde e educação), como em áreas de competência do município (como a regulamentação do solo urbano)" (p. 198). Assim, Silva confronta a visão de que as câmaras municipais são ineficientes e pouco relevantes na produção de políticas públicas e subalternas ao Poder Executivo. Segundo o autor, os vereadores desempenham papel importante na regulamentação de políticas

\footnotetext{
6 O autor analisou 14.716 projetos de lei apresentados por vereadores de 27 municípios brasileiros (amostra não representativa) das regiões Norte, Nordeste, Sul e Sudeste, de 2001 a 2011.
} 
sociais, podendo introduzir modificações substantivas nas proposições apresentadas pelos prefeitos e nas políticas implementadas em seus municípios.

Outra questão importante quando se trata de investigar as relações entre Executivo e Legislativo no nível municipal é saber se a prática de montagem de coalizões também é empregada pelos prefeitos para obter apoio na câmara. A questão consiste em saber como, a partir de que estratégias e com base em quais recursos, o prefeito obtém apoio para aprovar sua agenda na câmara e quão estável é esse apoio. Os partidos políticos desempenham algum papel de relevo nessa dinâmica, a exemplo do que ocorre nos níveis nacional e estadual?

Em uma das primeiras coletâneas dedicadas ao tema, Andrade (1998), Couto (1998) e Pralon e Ferreira (1998) investigam as relações entre prefeitos e vereadores no município de São Paulo durante as gestões de Luiza Erundina (1989-1992) e de Paulo Maluf (1993-1996). Os autores compartilham algumas premissas, entre elas: (1) os parlamentares estão interessados prioritariamente na continuidade de suas carreiras; (2) eles necessitam do apoio da máquina governamental para atender suas bases eleitorais e para assegurar seu sucesso eleitoral; e (3) o prefeito necessita do apoio do parlamento para aprovar sua agenda, o que o impele ao atendimento das demandas dos legisladores. Além disso, consideram que as características institucionais do sistema político brasileiro resultam na fragilidade organizacional dos partidos e em incentivos para uma atuação "atomizada dos legisladores, orientada sobretudo para o atendimento de demandas localizadas e particulares de suas bases político-eleitorais" (Couto, 1998, p. 59). A questão que emerge, portanto, é saber se, sob essas condições, Executivo e Legislativo poderiam ser levados a uma dinâmica de cooperação.

Os autores propõem diferentes modalidades de interação entre Executivo e Legislativo que podem incluir a construção de coalizões mediante distribuição de cargos, resultando em uma dinâmica mais estável; ou negociações pontuais entre um prefeito minoritário e os vereadores (Andrade, 1998). Consideram, ainda, que as relações podem tomar uma forma mais cooperativa ou mais conflituosa (Couto, 1998), assumir um caráter fisiológico ou programático. Pralon e Ferreira (1998), por sua vez, sugerem que a despeito dos incentivos do sistema eleitoral brasileiro para o comportamento individualista dos vereadores, há espaço para que os prefeitos adotem diferentes estratégias. De modo geral, os autores reconhecem que a ampliação da autonomia financeira dos municípios em relação ao governo federal, combinada aos novos poderes institucionais conferidos às câmaras municipais após a Constituição de 1988, teria resultado em um Poder Legislativo mais forte vis-à-vis o Executivo. A forma como os vereadores se valem de suas novas prerrogativas no exercício da representação e na relação com o Executivo, contudo, permanece objeto de controvérsia.

Nas duas décadas seguintes à publicação da coletânea organizada por Andrade (1998), outros estudos buscaram avançar na compreensão das relações ExecutivoLegislativo no nível municipal. Kerbauy (2005), em uma pesquisa com prefeitos e 
presidentes de câmaras municipais dos estados de São Paulo e Santa Catarina entre 2001 e 2003, mostrou que, segundo a percepção dos atores envolvidos, nem a submissão total nem o atrito permanente caracterizariam a relação entre Executivo e Legislativo. Caetano (2005), estudando o processo legislativo na Câmara Municipal de São Paulo no período de 2001 a 2004, também encontrou uma dinâmica diferente da descrita, por exemplo, por Lopez (2004) e Kuschnir (2000). O autor mostrou que o Executivo domina o conteúdo e o ritmo dos trabalhos legislativos - do total de projetos que se tornaram leis (398), 217 (55\%) foram de autoria do prefeito, enquanto os vereadores foram responsáveis por 181 (45\%). Nesse caso, o prefeito não estruturava o apoio à sua agenda no varejo por meio da liberação de recursos para os vereadores individualmente, mas a partir das prerrogativas institucionais reservadas a ele pela lei orgânica municipal, como a iniciativa exclusiva, a capacidade de veto e o poder de nomear e demitir seus secretários. Adicionalmente, segundo o autor, a centralização dos trabalhos legislativos na Câmara de São Paulo gerava incentivos para o comportamento partidário dos vereadores nas votações. Ainda de acordo com Caetano (2005), os elementos que estruturavam a formação de maiorias e a definição da agenda legislativa na Câmara de São Paulo a aproximavam do modelo partidário e da dinâmica descrita por Figueiredo e Limongi (1999), entre outros, para a Câmara dos Deputados.

Conclusão semelhante foi oferecida por Praça e Garcia (2011), investigando 39 municípios da região metropolitana de São Paulo de diferentes portes populacionais. Os autores mostraram que a construção do apoio ao Executivo se deu em moldes partidários por meio da montagem de coalizões via distribuição de cargos no gabinete, de forma semelhante ao observado no nível nacional e estadual (Figueiredo e Limongi, 1999; Santos, 2001; Ricci e Tomio, 2018). Garcia (2013), contudo, em trabalho posterior, mostrou que essa estratégia, isoladamente, não foi suficiente para assegurar maioria de apoio ao Executivo. Para a autora, o fato de que os prefeitos foram capazes de aprovar praticamente todos os projetos que chegaram ao plenário sugere a existência de estratégias complementares de construção de apoio. Ponto de vista diferente foi oferecido por Grin (2012), estudando a política de alianças no governo Marta Suplicy (2001-2004) em São Paulo. O autor identificou uma outra lógica nas nomeações de subprefeitos indicados pelos vereadores na construção do apoio ao Executivo, interpretada por ele na chave do fisiologismo e do clientelismo.

Os estudos mencionados apresentam evidências mistas no que se refere ao padrão de relacionamento entre os poderes no nível local. Além disso, a maioria dos estudos concentra-se nas capitais e municípios da região Sudeste. Na ausência de um número maior de estudos comparados sobre o tema, corremos o risco de inadequadamente elevarmos as características ou traços das unidades ou regiões mais estudadas e conhecidas ao status de paradigma nacional (Snyder, 2001, p. 99). Para avançar nessa agenda, dependemos de mais estudos comparados que incorporem municípios de diferentes regiões, perfis populacionais e características socioeconômicas. 


\section{Relações entre prefeitos e vereadores em Minas Gerais}

Neste artigo, analisamos as relações entre prefeitos e vereadores a partir de dados de opinião produzidos junto a uma amostra não representativa de 422 vereadores de 44 municípios de Minas Gerais eleitos em 2012 para a legislatura 2013-20167. Devido à sua extensão geográfica e diversidade demográfica, social e econômica, o estado ofereceu a possibilidade de selecionar municípios de diferentes perfis. Com efeito, em relação a vários aspectos, o estado de Minas Gerais costuma ser considerado uma espécie de amálgama do Brasil, combinando, nos limites de seu território, localidades com características típicas da região Sudeste, a mais rica e desenvolvida do país, com locais semelhantes aos da região Nordeste, que apresenta os piores indicadores socioeconômicos. O estado é o segundo maior colégio eleitoral do país e, segundo alguns analistas, é uma espécie de termômetro das eleições nacionais ${ }^{8}$.

Para a seleção dos municípios, usamos dois critérios de estratificação - número de habitantes (IBGE) e proporção de pobres (Atlas do Desenvolvimento Humano) - e selecionamos os municípios dentro de cada estrato ${ }^{9}$. A intenção inicial era entrevistar todos os vereadores, mas, do total de 489 vereadores, foi possível entrevistar 422 $(86,3 \%)^{10}$. Nossa amostra não é representativa do conjunto dos municípios ou dos vereadores mineiros e/ou brasileiros eleitos em 2012. Contudo, ela converge bastante com o perfil do total dos vereadores eleitos em Minas Gerais (quanto ao sexo e à escolaridade) e com o perfil do total dos municípios do estado (em relação ao número de habitantes e ao percentual de pobres).

Nunca é demais enfatizar que dados de opinião, obtidos por meio de entrevistas, não devem ser tomados como reflexo da realidade. Logo, os dados aqui analisados consistem em opiniões e percepções dos vereadores vocalizadas em um contexto

\footnotetext{
7 Ver nota de rodapé 2. A pesquisa contou com a participação de cerca de 20 estudantes de graduação e pós-graduação vinculados ao Núcleo de Estudos sobre Política Local (Nepol/PPGCSO/UFJF), aos quais expresso meus agradecimentos.

8 Ver "Minas Gerais é o retrato do quadro eleitoral do Brasil". Jornal GGN, 28 ago. 2018. Disponível em: <https://jornalggn.com.br/noticia/minas-gerais-e-o-retrato-do-quadro-eleitoral-do-brasil>. Acesso em: 12 set. 2018. Ver tamém: "Minas reflete distribuição de votos no país", Estado de Minas, 28 out. 2014. Disponível em: <https://www.em.com.br/app/noticia/politica/2014/10/28/interna_politica,584200/minasreflete-distribuicao-de-votos-no-pais.shtml>. Acesso em: 12 set. 2018.

9 Três estratos segundo o número de habitantes: municípios pequenos, com até 20 mil habitantes; médios, com mais de 20 mil até 100 mil habitantes; e grandes, com mais de 100 mil habitantes. Três estratos segundo nível de pobreza: municípios pobres, com mais de $40 \%$ da população em situação de pobreza; medianamente pobres, com mais de $20 \%$ até $40 \%$ da população em situação de pobreza; e ricos, com menos de $20 \%$ nessa situação. Consideramos o indicador do Atlas do Desenvolvimento Humano "proporção de pobres", que corresponde à proporção dos indivíduos com renda domiciliar per capita igual ou inferior a $\mathrm{R} \$ 140,00$ mensais, em agosto de 2010 (o universo de indivíduos é limitado àqueles que vivem em domicílios particulares permanentes).

10 Os principais motivos para a não realização das entrevistas foram: o vereador estava ausente do município (em viagem de trabalho ou em licença para tratamento médico) no período de permanência do entrevistador; o vereador era suplente que tinha acabado de assumir o cargo; impossibilidade de compatibilizar a agenda do vereador com a do entrevistador. Os casos de recusa explícita foram muito raros.
} 
específico, a saber, entrevistas presenciais levadas a cabo nos respectivos municípios por meio de questionário estruturado. Como tal, devem ser analisadas com cuidado e, sempre que possível, confrontadas com dados objetivos de comportamento.

Nesta seção, apresentamos os resultados da análise descritiva relativa às percepções dos vereadores no que se refere às suas relações com o Poder Executivo local. Optamos por uma apresentação detalhada dos dados tendo em vista a escassez de estudos comparados sobre o tema e com o intuito de oferecer ao leitor o máximo de elementos e subsídios para orientar futuras pesquisas.

Antes, porém, de apresentar os resultados da análise, é necessário um breve comentário sobre o termo "governismo" e seus usos na ciência política brasileira. O termo já foi mobilizado em diferentes ocasiões para se referir, principalmente: (1) à tendência dos prefeitos e elites locais de se alinharem aos governos de plantão (especialmente no plano nacional) como forma de assegurar acesso aos recursos do Estado e alimentar a clientela local; e (2) à tendência dos membros do Legislativo de aderirem ao governo de ocasião, posicionando-se de forma mais vantajosa para acessar recursos cruciais para a sua sobrevivência política. No segundo caso, o governismo desempenharia um papel central na formação de maiorias de governo, sendo responsável pelo enfraquecimento das oposições no Legislativo.

A primeira acepção do termo pode ser encontrada em Leal (2012 [1948]) para se referir a uma das bases do sistema político na República Velha e em Lamounier (2009 [1978]) como "governismo de clientela" (p. 39 e p. 97) em sua análise das eleições municipais de 1976. Mais recentemente, também na primeira acepção, é possível encontrar referência ao termo governismo em Zucco (2010) e em Power e RodriguesSilveira (2019). Os últimos se referem ao governismo como sinônimo de "alinhamento político vertical", a tendência das elites políticas locais, especialmente nos municípios mais pobres, de "se alinharem ao governo nacional, presumivelmente porque sua sobrevivência política depende de transferências de outros recursos usualmente concedidos a partir de Brasília" (Power e Rodrigues-Silveira; 2019, p. 22; tradução nossa).

Na sua segunda acepção, o termo é usado para se referir a uma tendência dos legisladores de se alinharem ao Poder Executivo, independentemente de quem esteja no governo. Esse é o uso feito por Abrúcio (1998) em seu estudo sobre as relações Executivo-Legislativo no estado de São Paulo para designar o padrão de atuação dos parlamentares que votam com os governadores porque sua sobrevivência política depende de recursos controlados pelo Executivo. Em sentido semelhante, o termo é mobilizado por Melo (2002) para se referir à prática observada na Câmara dos Deputados entre 1985 e 2001 de os parlamentares mudarem de partido após eleitos, migrando predominantemente para a base do governo. O termo também foi usado por Kinzo (1990) para designar a tendência de um partido votar com o governo. Neste artigo, usamos o termo na segunda acepção, como tendência dos membros do parlamento de se 
alinharem com o Executivo, aprovarem suas iniciativas e relegarem ao segundo plano a função de fiscalização. Mas, aqui, o governismo é captado não a partir de indicadores objetivos de comportamento, e sim por meio de dados de opinião produzidos junto a vereadores em municípios de Minas Gerais.

\section{Quão disseminado é o governismo?}

Os dados mostram (Tabela 1) que o governismo é menos difundido do que se poderia esperar a partir da imagem disseminada pela literatura. Entre os entrevistados, $54,2 \%$ se declararam pró-governo, contra $34,7 \%$ e $11,2 \%$, que se declararam próoposição e independentes, respectivamente. O governismo, aqui mensurado a partir da resposta dos vereadores sobre sua posição em relação ao governo, é menor nos municípios de porte médio (com população maior que 20 mil até 100 mil habitantes) e bem semelhante entre os municípios pequenos e grandes, diferença que se revelou estatisticamente significativa. Os municípios pequenos, muitas vezes retratados como espaços dominados por chefes políticos locais, foram os que apresentaram maior percentual de vereadores que se declararam da oposição e menor percentual de vereadores que se declararam independentes. Esse dado converge com a imagem dos pequenos municípios como cenário de uma política muito combativa na qual é imperativo escolher um lado, sendo malvista a postura "em cima do muro".

Tabela 1

Posição em relação ao governo por porte do município - \% (N)

\begin{tabular}{|l|c|c|c|}
\hline & Governo & Oposição & Independente \\
\hline \multirow{2}{*}{ Pequeno } & 56,8 & 32,7 & 6,0 \\
& $(142)$ & $(93)$ & $(15)$ \\
\hline \multirow{2}{*}{ Médio } & 46,1 & 30,3 & 23,7 \\
& $(35)$ & $(23)$ & $(18)$ \\
\hline \multirow{2}{*}{ Grande } & 53,7 & 31,6 & 14,7 \\
& $(51)$ & $(30)$ & $(14)$ \\
\hline \multirow{2}{*}{ Total } & 54,2 & 34,7 & 11,2 \\
& $(228)$ & $(146)$ & $(47)$ \\
\hline
\end{tabular}

Fonte: Elaboração própria com base em Nepol/PPGCSO/UFJF (2015).

Nota: Pearson's chi-square test $-\mathrm{p}$-value $=, 001$.

Como não conseguimos entrevistar todos os vereadores de todos os municípios, não é possível classificar com precisão todas as câmaras municipais quanto à sua posição em relação ao Executivo. Considerando o número de vereadores entrevistados, é possível afirmar que temos 18 câmaras governistas, com uma maioria absoluta de vereadores, sobre o total do município, que se declarou governista; e 13 câmaras oposicionistas, nas quais uma maioria absoluta se declarou da oposição/independente ou, para o caso das câmaras em que não conseguimos entrevistar a totalidade dos vereadores, o número que declarou ser de oposição/independente já é suficiente para bloquear uma maioria 
absoluta a favor do Executivo considerando o número total de membros da casa. Não pudemos definir o perfil das outras 13 câmaras porque o número de entrevistas não realizadas impossibilitou classificá-las como governistas ou oposicionistas ${ }^{11}$. Consideramos que esse quadro, longe de atestar uma tendência generalizada para o governismo dos vereadores e das câmaras municipais, sugere, na verdade, um cenário mais complexo de relacionamento entre os poderes no nível municipal.

As informações sobre coligações nos permitem complementar a análise oferecendo pistas sobre a forma e o momento em que os campos situacionista e oposicionista se formam, se antes da eleição, ainda na montagem das chapas, assim se mantendo após a definição do resultado; ou se após a eleição, como resultado de esforços do prefeito eleito para incluir e acomodar novos atores e forças no campo situacionista, e/ou pela movimentação dos próprios vereadores, no sentido de se aproximarem do Poder Executivo.

A Tabela 2 mostra que, para a maioria dos vereadores, o alinhamento em relação ao prefeito foi definido antes das eleições, na montagem das chapas. De cada dez governistas, sete eram de partidos que já estavam alinhados ao prefeito na coligação eleitoral. E apenas três se alinharam depois da eleição. E, de cada dez vereadores que não faziam parte da coligação do prefeito, 6 permaneceram na oposição ou como independentes depois da eleição. Novamente a diferença entre os grupos mostrou-se estatisticamente significativa. Dos 68 vereadores que não faziam parte da coligação e depois passaram a apoiar o prefeito, $51,5 \%$ eram de municípios pequenos, o que mostra que a atração de vereadores de fora da coligação para a base do prefeito foi mais comum nesses cenários.

Tabela 2

Alinhamento ao prefeito antes e depois da eleição - \% (N)

\begin{tabular}{|l|c|c|c|}
\hline \multicolumn{2}{|c|}{} & \multicolumn{2}{c|}{ Vereador apoia o prefeito? } \\
\hline \multirow{2}{*}{$\begin{array}{l}\text { Vereador é da coligação que } \\
\text { elegeu o prefeito }\end{array}$} & \multirow{2}{*}{$\operatorname{Sim}$} & $\begin{array}{c}75,1 \\
\text { Não }\end{array}$ \\
\cline { 2 - 4 } & \multirow{2}{*}{ Não } & $(160)$ & 24,9 \\
& 32,7 & $(53)$ \\
\cline { 3 - 4 } & & $(68)$ & $(140)$ \\
\hline
\end{tabular}

Fonte: Elaboração própria com base em Nepol/PPGCSO/UFJF (2015).

Nota: Pearson's chi-square test $-\mathrm{p}$-value $=, 001$.

A pesquisa também revelou que $89,9 \%$ dos vereadores que eram do partido do prefeito declararam apoiá-lo. Entre os que eram de partido diferente, apenas 45,9\% declararam-se governistas (sendo a diferença entre os grupos estatisticamente

\footnotetext{
11 Para fins de simplificação, contabilizamos os independentes entre os oposicionistas. Consideramos que, se a tentação para o governismo é tão grande, como sugere a literatura, a posição de independente tenderia a fortalecer o eixo da oposição.
} 
significativa ao nível de 0,01). Nos três perfis de município - pequeno, médio e grande -, mais de $85 \%$ dos vereadores que eram do partido do prefeito declararam apoiá-lo.

Do total de vereadores entrevistados, 48 pertenciam ao mesmo partido do candidato que ficou em segundo lugar na eleição para prefeito. Destes, $13(27,1 \%)$ declararam apoiar o prefeito eleito, contra $57,6 \%$ que pertenciam a outros partidos. Dos 13 vereadores que eram do partido do segundo colocado e aderiram ao prefeito eleito, 9 eram de municípios pequenos, corroborando a tese de maior governismo nesses cenários. $O$ fato de que as diferenças entre os grupos são significativas (ao nível de 0,01) sugere que 0 alinhamento partidário com 0 candidato derrotado exerce algum constrangimento à adesão do vereador à situação após a eleição.

A continuidade no posicionamento da maioria dos vereadores antes e depois das eleições parece sugerir uma dinâmica na qual dois ou mais grupos rivalizam pelo poder no município, e a maior parte dos perdedores prefere aguardar a próxima rodada a se incorporar ao grupo vencedor. Os dados também sugerem que a filiação partidária tem alguma implicação prática na definição do posicionamento político dos vereadores, com um peso menor nos municípios pequenos.

Para oferecer ao leitor uma melhor medida do governismo no nível local, é útil comparar os números apresentados com os dos dois governos em exercício nos níveis estadual e nacional à época em que as entrevistas foram realizadas. A coligação que reelegeu Dilma Rousseff em 2014 era formada por nove partidos - PT, PMDB, PDT, PCdoB, PP, PR, PSD, PROS e PRB -, que elegeram, juntos, o correspondente a $59,2 \%$ das cadeiras na Câmara dos Deputados. Um ano depois, o PTB foi incorporado à coalizão, totalizando dez partidos e $64,1 \%$ das cadeiras. A coligação que elegeu Fernando Pimentel governador de Minas Gerais em 2014 era formada por cinco partidos - PT, PMDB, PRB, PROS e PCdoB, que, juntos, conquistaram 34\% das cadeiras na Assembleia Estadual. $O$ PR foi posteriormente incorporado à coalizão (com cargo no secretariado), que passou a ser formada por seis partidos e a contar com o apoio de $38 \%$ dos deputados ${ }^{12}$. Mas um mês após a posse do governador, Fernando Pimentel passou a contar com uma maioria folgada de $67,5 \%$ dos deputados estaduais com a adesão de outros 23 parlamentares de 10 partidos diferentes, entre eles PPS, PSB e PSD, partidos que tinham feito parte dos governos anteriores do PSDB e ocupado cargos importantes no núcleo dos governos tucanos ${ }^{13}$. Tanto no nível estadual como no nacional, vimos o movimento de parlamentares e partidos que se deslocaram da posição de independentes ou de franca oposição para a de alinhamento ao governo. Nossos achados mostram que o mesmo

\footnotetext{
12 Tanto no governo de Dilma Rousseff quanto no de Fernando Pimentel, consideramos como parte da coalizão os partidos que tinham cargos no primeiro escalão do governo. Nos dois casos, o PROS integrou a coligação eleitoral, mas não foi contemplado com nenhum cargo nos governos.

13 Esses parlamentares formavam um bloco independente denominado Compromisso com Minas e, por meio de seu líder, confirmaram o apoio aos projetos do governo de Fernando Pimentel. Disponível em: <https://redehoje.com.br/index.php/gerais/2399-fernando-pimentel-consegue-apoio-da-maioria-dosparlamentares-na-almg>. Acesso em: 5 nov. 2020.
} 
ocorre no nível municipal, especialmente nos municípios menores, mas em proporção menor do que seria de esperar tendo em vista a literatura sobre o tema, que, em grande medida, tendeu a enfatizar o governismo dos vereadores e a fragilidade das câmaras municipais perante o Executivo. As evidências apresentadas nas próximas subseções reforçam esse argumento.

\section{Estratégias e recursos na construção do apoio}

Nesta subseção buscamos identificar as estratégias e os recursos priorizados pelo prefeito na construção do apoio na câmara, sob a ótica dos vereadores. Perguntamos aos vereadores "como o prefeito faz para conseguir apoio na câmara municipal". Devido ao escasso número de estudos sobre o tema, optamos por permitir a resposta espontânea dos entrevistados. Reunimos as respostas em cinco grandes grupos. No primeiro grupo, foi curioso observar que $22 \%$ dos entrevistados afirmaram que o prefeito "não faz nada", apenas envia os projetos para a câmara $(13,4 \%)$ ou não faz nada porque já tem uma maioria e apenas a mobiliza (8,5\%). Esse dado talvez possa ser explicado pelo fato, já destacado, de que o alinhamento ao prefeito, na maioria dos casos, remonta à criação das chapas, no período eleitoral. Nesse sentido, a definição dos campos situacionista e oposicionista seria mais resultado das urnas do que de esforços de negociação e acomodação posteriores às eleições.

Em um segundo grupo temos os que enfatizaram a dimensão do diálogo e a da persuasão combinados à negociação e que correspondem a 39,8\% da amostra. Nesse caso, as expressões mais utilizadas foram "explica o projeto", "apresenta o projeto", realiza reuniões para "explicar, negociar e conversar", "explica o projeto coletiva ou individualmente", "mantém um bom relacionamento e diálogo permanente com a câmara".

No terceiro grupo temos os que enfatizaram explicitamente as estratégias de negociação e barganha no estilo "toma-lá-dá-cá" e que correspondem a apenas 11,2\% dos entrevistados. Nesse grupo, os vereadores destacaram os esforços do prefeito para atender às demandas dos vereadores e de seus eleitores, e a distribuição de cargos e nomeações para empregos públicos.

Um quarto grupo se caracterizou por respostas que poderíamos chamar de politicamente corretas $(15,9 \%)$. Os vereadores não destacaram nenhuma estratégia específica, afirmando que a forma de o prefeito conquistar o apoio da câmara é enviando "projetos de interesse/benefício da população", "projetos corretos" e "coerentes", "enviando bons projetos para a câmara" e "fazendo uma boa administração". Com isso, sugerem que, se o prefeito quiser o apoio dos vereadores, basta que apresente propostas de qualidade condizentes com o interesse público, não sendo necessário lançar mão de nenhum incentivo individual. 
Em uma quinta e última categoria, reunimos aqueles que não citaram nenhuma estratégia específica, preferindo enfatizar o grupo focado ou o mediador utilizado e as respostas mais vagas e ambíguas que não permitem uma interpretação inequívoca como: "por meio do presidente da câmara", "faz pressão", "fica a critério dos vereadores e assessores analisar e avaliar os projetos" (o que sugere uma postura mais ativa para os vereadores) e "envia o projeto e pede apoio". Essas respostam representam $11,2 \%$ do total.

O Gráfico 1 apresenta os dados agrupados por posição em relação ao prefeito (com oposição incluindo independentes) e o resultado do teste de qui-quadrado que atesta uma diferença estatisticamente significativa entre os grupos. É interessante notar que a barganha e a troca de favores foram quatro vezes mais frequentes nas respostas dos vereadores de oposição e independentes, aqueles que, provavelmente, não são os alvos prioritários dessas negociações. Entre os que apoiam o governo, foi muito mais frequente a ênfase no diálogo e na persuasão, aliados à negociação.

Gráfico 1

Principal maneira de o prefeito buscar conquistar o apoio dos vereadores (\%)

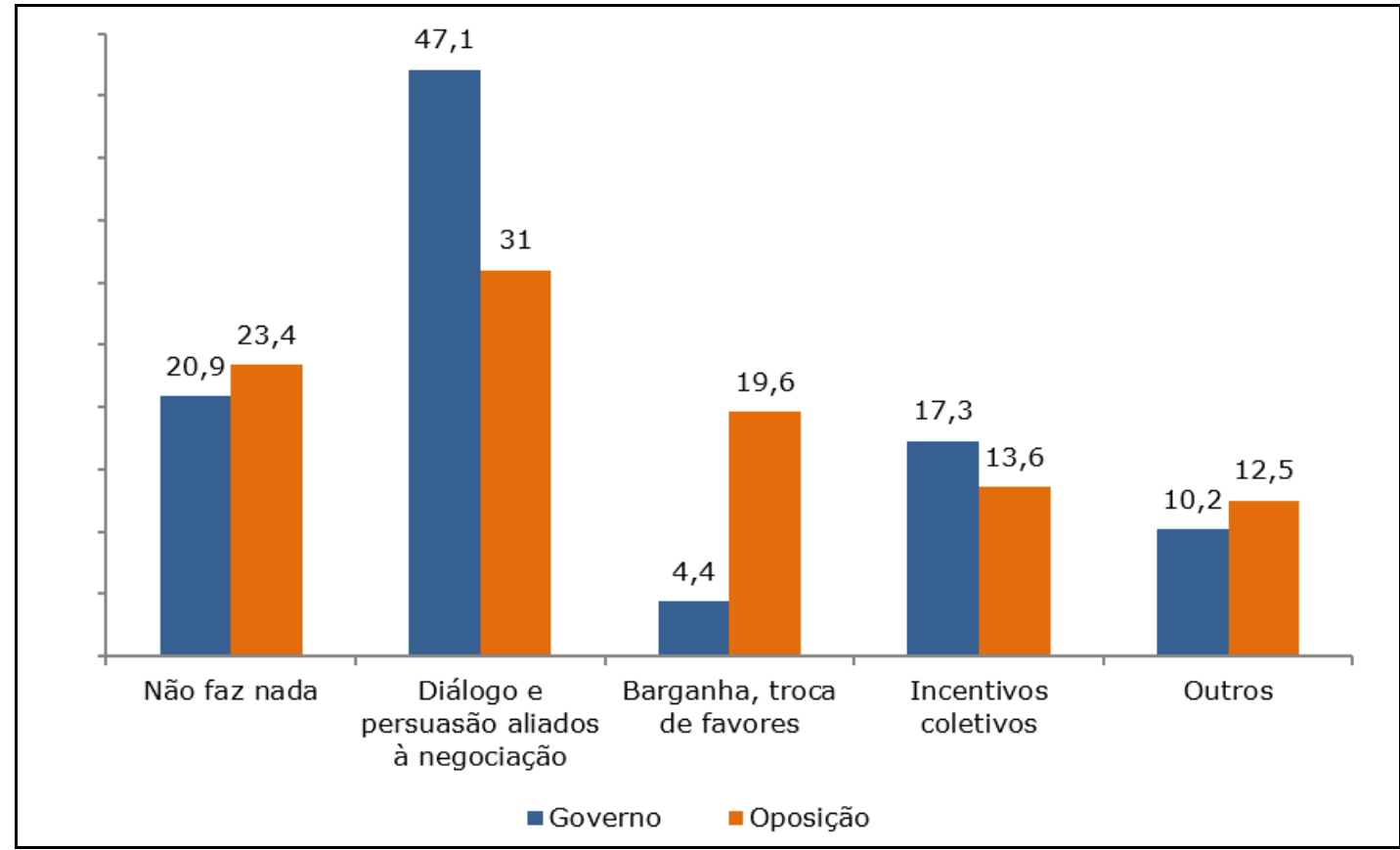

Fonte: Elaboração própria com base em Nepol/PPGCSO/UFJF (2015).

Nota: Pearson's chi-square test - p-value $=, 001$.

Parte das respostas indica que o prefeito não teria muito trabalho a fazer, podendo contar com uma maioria segura (talvez construída antes das eleições, no momento de montagem das chapas) a ser mobilizada. Outra parte corrobora a ideia de 
uma troca de favores na qual o prefeito atende às demandas dos vereadores e de seus eleitores e estes, em troca, dão o apoio requerido votando a favor dos projetos do prefeito. Essa interpretação sugere um processo que ocorreria no varejo, tendo em vista os interesses individuais dos vereadores, o que converge com alguns estudos como o de Lopez (2004). Os dados, porém, são apenas sugestivos, porque não perguntamos explicitamente aos vereadores se a negociação se dá individualmente ou se ocorre em bloco com a mediação das lideranças partidárias. O próprio papel desses líderes precisa ser investigado no contexto da política municipal, questão que abodaremos na sequência.

Além da barganha, as respostas dos vereadores, principalmente dos governistas, sugerem espaço para debate, persuasão e diálogo na construção do apoio ao Executivo. Nesse caso, como no anterior, o apoio ao prefeito não seria garantido, mas dependeria de uma postura ativa dos prefeitos e de seus aliados e assessores no sentido de persuadir os vereadores, seja por meio do diálogo puro e simples ou por meio da troca de favores. Existe, claro, a possibilidade de que os vereadores, em suas respostas, busquem exaltar sua independência em relação ao prefeito, escondendo sua tendência de aprovar, sem mais, as iniciativas legislativas do Executivo.

Os aspectos reunidos no quarto grupo devem ser encarados com crítica porque podem padecer do viés da resposta socialmente desejável. Afinal, pode não ser muito confortável para os vereadores admitirem que condicionam seu apoio à obtenção de benefícios individuais e particulares, sem considerar os efeitos dos projetos para a coletividade e a sua qualidade do ponto de vista técnico. As diferenças entre as respostas de governistas e oposicionistas sugerem que seja mais fácil para os que não participam das trocas e negociações admitir que elas são elementos cruciais para a construção do apoio.

\section{Líderes, liderados e mediação na construção do apoio ao Executivo}

Na literatura sobre as relações entre Executivo e Legislativo no nível nacional, a coordenação partidária e a atuação dos líderes na construção do apoio legislativo ao Executivo são entendidas a partir de sua contribuição para superar problemas de ação coletiva no processo decisório (Santos, 2002; Figueiredo e Limongi, 1999). Em outras palavras, entende-se que a negociação em bloco é racional para o Executivo e para os legisladores. Para o primeiro, seria menos custoso negociar com meia dúzia de líderes capazes de fazer promessas críveis e mobilizar o apoio necessário em bloco do que negociar com dezenas ou centenas de parlamentares individualmente. Além da possibilidade de economizar em termos do volume de recursos a serem distribuídos, o chefe do Executivo se veria livre da necessidade de produzir informação precisa sobre as preferências e inclinações de cada um dos legisladores. Para os parlamentares, a negociação do apoio em bloco também seria racional porque ampliaria seu poder de barganha ao tornar as ameaças de defecção, em bloco, mais persuasivas. Contudo, esse 
raciocínio, bastante influente nas explicações sobre o processo de delegação do Legislativo para o Executivo no nível nacional, pode não ser o mais adequado quando deslocamos nosso olhar para os municípios tendo em vista a dimensão das câmaras e a própria natureza das demandas - bem menos complexas, em muitos casos direcionadas ao sistema político local.

$\mathrm{Na}$ grande maioria dos municípios brasileiros, com população menor que 50 mil habitantes e câmaras com, no máximo, 13 vereadores ${ }^{14}$, o problema de ação coletiva ao qual nos referimos pode simplesmente não existir ou não ser relevante a ponto de incentivar a delegação e a negociação no atacado. Conforme sugerem Silva e Dantas (2017), no contexto das câmaras municipais, "ao invés de serem necessários mecanismos institucionais, a fim de gerar cooperação política, as negociações são mais informais e apelam para o protagonismo de 'empreendedores individuais'" (p. 19).

Perguntamos aos vereadores sobre a distribuição de poder no interior da câmara municipal. Nossa expectativa era que a distribuição desigual de poder seria maior nos municípios e nas câmaras maiores. Esta poderia ser vista tanto como uma resposta a problemas de coordenação quanto como resultado da maior complexidade do ambiente e da própria organização. A Tabela 3 apresenta as respostas por porte do município e corrobora nossas expectativas, com diferenças estatisticamente significativas. Dois terços dos vereadores afirmaram que existe assimetria de poder entre os vereadores. Quanto maior o município e, logo, o número de vereadores da câmara, maior o percentual de vereadores que afirmaram existir assimetria de poder no interior da casa.

Tabela 3

Opinião dos vereadores sobre distribuição de poder no interior da câmara municipal - \% (N)

\begin{tabular}{|l|c|c|}
\hline & $\begin{array}{c}\text { Todos os vereadores têm o } \\
\text { mesmo poder e influência }\end{array}$ & $\begin{array}{c}\text { Alguns vereadores têm mais } \\
\text { poder e influência do que outros }\end{array}$ \\
\hline \multirow{2}{*}{ Pequeno } & 42,6 & 57,4 \\
$(107)$ & $(144)$ \\
\hline \multirow{2}{*}{ Médio } & 28,0 & 72,0 \\
& $(21)$ & $(54)$ \\
\hline \multirow{2}{*}{ Grande } & 15,8 & 84,2 \\
& $(15)$ & $(80)$ \\
\hline \multirow{2}{*}{ Total } & 34,0 & 66,0 \\
\end{tabular}

Fonte: Elaboração própria com base em Nepol/PPGCSO/UFJF (2015).

Nota: Pearson's chi-square test $-\mathrm{p}$-value $=, 001$.

Mas em que se baseia a distribuição desigual de poder entre os vereadores? Dado o baixo grau de institucionalização da maioria das câmaras municipais brasileiras, nossa expectativa era que a distribuição de poder poderia ser mais orientada por fatores exógenos à instituição do que por incentivos gerados internamente. Ao elaborar as

14 Emenda Constitucional no 58, de 2009. 
alternativas de resposta, também objetivamos avaliar o grau de influência do prefeito na dinâmica interna à câmara. A Tabela 4 mostra os resultados por porte do município:

Tabela 4

Por que alguns vereadores têm mais poder e influência do que outros? - \% (N)

\begin{tabular}{|c|c|c|c|c|c|c|c|}
\hline & $\begin{array}{c}\text { Ocupam } \\
\text { cargo } \\
\text { importan } \\
\text { te dentro } \\
\text { da } \\
\text { câmara }\end{array}$ & $\begin{array}{c}\text { Têm } \\
\text { muitos } \\
\text { mandatos } \\
\text { são } \\
\text { experient } \\
\text { es }\end{array}$ & $\begin{array}{c}\text { Tivera } \\
\text { m } \\
\text { muito } \\
\text { s } \\
\text { votos }\end{array}$ & $\begin{array}{c}\text { São } \\
\text { pessoas } \\
\text { conhecidas } \\
\text { e } \\
\text { respeitada } \\
\text { s no } \\
\text { município } \\
\end{array}$ & $\begin{array}{c}\text { Têm } \\
\text { boas } \\
\text { relaçõe } \\
\text { s com } \\
\text { o } \\
\text { prefeit } \\
0 \\
\end{array}$ & $\begin{array}{c}\text { Ocupam } \\
\text { cargo } \\
\text { importan } \\
\text { te no } \\
\text { partido }\end{array}$ & $\begin{array}{c}\text { Outro } \\
\text { motivo }\end{array}$ \\
\hline Pequeno & $\begin{array}{l}5,6 \\
(8)\end{array}$ & $\begin{array}{l}21,0 \\
(30)\end{array}$ & $\begin{array}{l}2,8 \\
(4)\end{array}$ & $\begin{array}{l}11,2 \\
(16)\end{array}$ & $\begin{array}{l}32,2 \\
(46)\end{array}$ & $\begin{array}{l}0,7 \\
(1)\end{array}$ & $\begin{array}{l}26,6 \\
(38)\end{array}$ \\
\hline Médio & $\begin{array}{c}11,1 \\
(6)\end{array}$ & $\begin{array}{l}27,8 \\
(15)\end{array}$ & $\begin{array}{l}0,0 \\
(0)\end{array}$ & $\begin{array}{c}14,8 \\
(8)\end{array}$ & $\begin{array}{l}24,1 \\
(13)\end{array}$ & $\begin{array}{l}0,0 \\
(0)\end{array}$ & $\begin{array}{l}22,2 \\
(12)\end{array}$ \\
\hline Grande & $\begin{array}{l}6,3 \\
(5)\end{array}$ & $\begin{array}{l}30,0 \\
(24)\end{array}$ & $\begin{array}{l}0,0 \\
(0)\end{array}$ & $\begin{array}{l}12,5 \\
(10)\end{array}$ & $\begin{array}{l}32,5 \\
(26)\end{array}$ & $\begin{array}{l}0,0 \\
(0)\end{array}$ & $\begin{array}{l}18,8 \\
(15)\end{array}$ \\
\hline Total & $\begin{array}{c}6,9 \\
(19)\end{array}$ & $\begin{array}{l}24,9 \\
(69)\end{array}$ & $\begin{array}{l}1,4 \\
(4)\end{array}$ & $\begin{array}{l}12,3 \\
(34)\end{array}$ & $\begin{array}{l}30,7 \\
(85)\end{array}$ & $\begin{array}{l}0,4 \\
(1)\end{array}$ & $\begin{array}{l}23,5 \\
(65)\end{array}$ \\
\hline
\end{tabular}

Fonte: Elaboração própria com base em Nepol/PPGCSO/UFJF (2015).

Nos municípios pequenos e grandes, os fatores mais decisivos para explicar a posição de destaque de certos vereadores foram a manutenção de boas relações com o prefeito e a experiência, medida em número de mandatos. Nos municípios médios, as duas alternativas foram as mais destacadas, mas em ordem inversa. Segundo os entrevistados, a ocupação de cargos nas organizações partidárias e o desempenho eleitoral não se traduzem em mais poder e influência no interior da instituição. Já a notabilidade social apareceu em terceiro lugar nos três tipos de municípios. É interessante observar que os fatores endógenos à câmara, que remetem aos incentivos internos à organização legislativa, como ocupação de cargos e número de mandatos como vereador, foram assinalados por menos de um terço do total de entrevistados, recebendo ainda menos destaque nos municípios pequenos. Esse dado corrobora a hipótese de um baixo nível de institucionalização das câmaras, especialmente nos municípios de pequeno porte. Os dados também fortalecem a tese do governismo, sugerindo que a manutenção de boas relações com o prefeito seja uma estratégia importante para o vereador se destacar. Contudo, é importante lembrar que, para um terço dos vereadores, a questão não se aplicou porque, segundo eles, simplesmente não existe distribuição desigual de poder entre os legisladores.

Que diferença isso faz? O que ganham e o que perdem os vereadores em função de seu posicionamento?

Em outra questão de resposta espontânea, perguntamos aos vereadores se fazia diferença para o seu trabalho apoiar ou não o prefeito e pedimos que justificassem sua 
resposta. Nosso objetivo era verificar a hipótese segundo a qual o alinhamento ao governo seria uma estratégia fundamental para os legisladores terem acesso a recursos e serem capazes de atender às demandas de seus eleitores; portanto, crucial para a sua sobrevivência política. Da mesma forma, buscamos investigar se permanecer na oposição implicaria, de fato, altos custos para os vereadores, tendo em vista o desenho institucional que concentra no Executivo a maior parte das prerrogativas decisórias e dos recursos políticos.

Apenas um quarto dos entrevistados $(25,8 \%)$ afirmou que NÃO faz diferença para o vereador se ele apoia ou não o prefeito, confirmando a relevância desse ator na arena municipal. A maior parte dos entrevistados $(73,5 \%)$ foi explícita em afirmar que faz SIM diferença para os vereadores se eles apoiam ou não o chefe do Executivo. A percepção de que o apoio ao prefeito impacta o trabalho do vereador é ligeiramente maior entre os vereadores dos municípios grandes. Mas o teste qui-quadrado mostra não haver diferença estatisticamente significativa ( $p$ valor $=446)$, seja em função do porte do município, seja em função da posição em relação ao prefeito (Gráfico 2). Os percentuais que disseram fazer diferença para o vereador se ele apoia ou não o prefeito foram praticamente os mesmos entre vereadores governistas (74\%) e não governistas $(74,3 \%)$.

Gráfico 2

Faz diferença se o vereador apoia o prefeito? Por porte do município (\%)

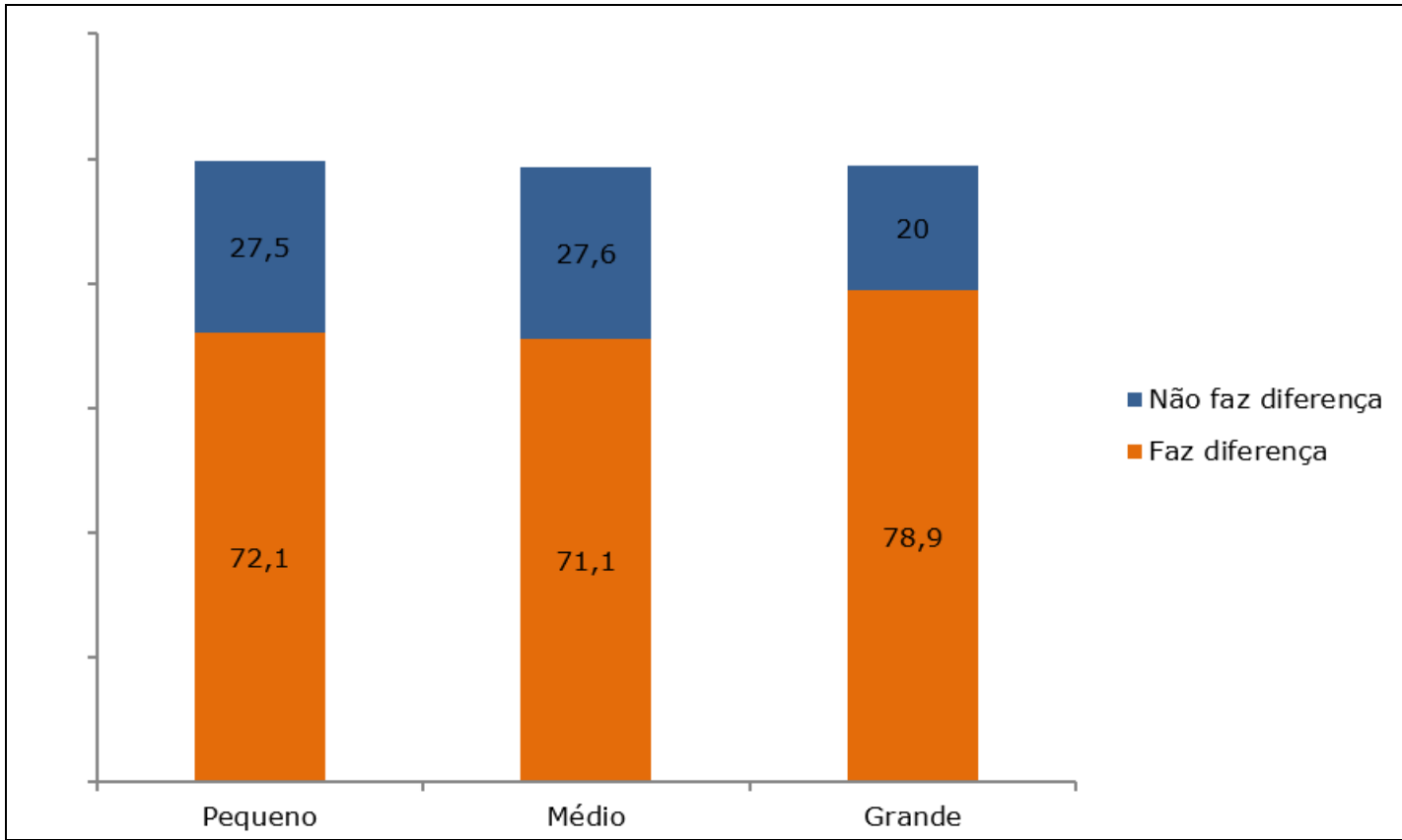

Fonte: Elaboração própria com base em Nepol/PPGCSO/UFJF (2015).

Nota: Pearson's chi-square test $-\mathrm{p}$-value $=, 446$. 
Entre os que afirmaram fazer SIM diferença, as principais justificativas foram, na ordem: "quem apoia recebe mais ajuda/tem mais facilidade/atenção/visibilidade", "é o prefeito quem controla os recursos", "quem não apoia tem mais independência", "quem não apoia sofre perseguição". As principais justificativas de quem afirmou que NÃO faz diferença foram, na ordem: "os poderes são independentes", "o prefeito atende a todos", "o prefeito não atende ninguém", "o trabalho depende apenas do vereador", "o que importa é se o projeto é bom para o município". O fato de a maioria dos entrevistados afirmar que apoiar o prefeito significa mais apoio, facilidades, atenção e visibilidade corrobora um aspecto já destacado pelos estudiosos sobre um dos fundamentos do governismo nos municípios.

Ao justificar a importância do apoio ao prefeito, a maioria dos vereadores manteve o foco no exercício do mandato e na forma como sua posição favorece ou dificulta o alcance de seus objetivos, entre eles o de atender aos seus eleitores. Mas, especificamente em relação ao processo eleitoral, faz diferença para o vereador se ele esteve ou não alinhado ao prefeito? Especificamente no caso da política local, poderíamos supor que o apoio do prefeito ou do candidato a prefeito daria maior visibilidade ao candidato a vereador e poderia ser tomado, pelos eleitores, como sinal de prestígio e de acesso a recursos importantes, aumentando a credibilidade das promessas feitas.

Buscamos apreender a importância do prefeito ou de um candidato a prefeito para a vitória do vereador na última eleição. Perguntamos aos vereadores qual apoio foi o mais importante para a sua eleição. A figura do prefeito em exercício e/ou a de um candidato a prefeito não receberam destaque, sendo apontadas apenas por $4,8 \% \mathrm{e}$ $1,9 \%$, respectivamente, e em terceiro lugar, depois de familiares e amigos $(68,4 \%)$ e de movimentos sociais, associações ou sindicatos (14,7\%). Mesmo nos municípios pequenos e entre os vereadores governistas, a figura do prefeito em exercício à época ou a de um candidato a prefeito não receberam destaque. Essas respostas sugerem que o impacto do apoio de prefeitos e/ou de candidatos a prefeito sobre o sucesso ou o fracasso eleitoral dos vereadores pode estar sendo superdimensionado pelos analistas.

É sabido que parte importante do trabalho dos vereadores consiste em apresentar indicações com solicitações à administração municipal de tomada de providências e solução de problemas dos mais diversos tipos. Esse seria um canal formal de atuação dos vereadores em prol de seus eleitores. De fato, $73 \%$ dos vereadores entrevistados afirmaram ter apresentado muitas vezes indicações e 19,7\% afirmaram que apresentaram algumas vezes. Trabalhando com a mesma base de dados, Rocha e Silva (2017) observaram que "vereadores que apoiam o governo apresentam mais indicações e têm mais sucesso em vê-las atendidas quando comparados com vereadores da oposição e independentes". Contudo, também é possível que os vereadores se valham de seu acesso direto aos órgãos e agentes municipais, buscando soluções de modo mais informal (ou mesmo para reforçar as solicitações e ações formais). Para mensurar a dimensão do acesso, perguntamos aos vereadores com que frequência, na legislatura 
2013-2016, fizeram contato com prefeitos e secretários para solicitar atendimento de demandas dos eleitores. A Tabela 5 mostra os resultados considerando a posição do vereador em relação ao governo, por porte do município:

Tabela 5

Com que frequência fez contato com prefeito e/ou secretários para solicitar atendimento de demandas dos eleitores? Por porte do município e posição em relação ao prefeito (\%)

\begin{tabular}{|c|c|c|c|c|c|}
\hline & & Nunca & Raramente & $\begin{array}{c}\text { Algumas } \\
\text { vezes }\end{array}$ & $\begin{array}{c}\text { Muitas } \\
\text { vezes }\end{array}$ \\
\hline \multirow{2}{*}{ Pequeno } & Governo & 2,8 & 2,1 & 19,0 & 76,1 \\
\hline & Oposição/independente & 8,3 & 8,3 & 34,3 & 49,1 \\
\hline \multirow{2}{*}{ Médio } & Governo & 0,0 & 8,6 & 8,6 & 82,9 \\
\hline & Oposição/independente & 4,9 & 17,1 & 17,1 & 61,0 \\
\hline \multirow{2}{*}{ Grande } & Governo & 0,0 & 3,9 & 19,6 & 76,5 \\
\hline & Oposição/independente & 2,3 & 20,5 & 34,1 & 43,2 \\
\hline Total & & 5,2 & 4,8 & 25,6 & 64,4 \\
\hline
\end{tabular}

Fonte: Elaboração própria com base em Nepol/PPGCSO/UFJF (2015).

Nota: Pearson's chi-square test - $\mathrm{p}$-value municípios pequenos $=, 001$. Pearson's chi-square test - $\mathrm{p}$-value municípios grandes $=, 005$. Pearson's chi-square test $-\mathrm{p}$-value municípios médios $=, 168$

Nos três tipos de município, a grande maioria dos vereadores afirmou ter feito contato algumas ou muitas vezes com o prefeito e/ou membros da administração municipal. A proporção dos vereadores que se valeram desses contatos com frequência é expressivamente maior entre os que apoiam o governo do que entre os que não o apoiam. Mas apenas nos municípios pequenos e grandes as diferenças entre governistas e não governistas foram estatisticamente significativas. Esse dado converge com a constatação de Kuschnir (2000) sobre a importância dos "acessos" na política municipal, em outras palavras, quão decisiva pode ser para o vereador a proximidade em relação aos órgãos e às autoridades públicas. Essa proximidade e o acesso podem ser fundamentais em diferentes aspectos - partidários, pessoais, políticos -, mas é sempre crucial para assegurar o atendimento aos eleitores e, consequentemente, se posicionar de forma mais favorável eleitoralmente.

Os dados parecem corroborar a tese de que o alinhamento ao governo é fundamental para que os vereadores sejam capazes de atender seus eleitores e assegurar seu sucesso político e eleitoral. Igualmente, corrobora, em parte, a ideia de que fazer oposição implicaria altos custos para os vereadores, que encontrariam uma série de dificuldades para atender seus eleitores e teriam menor acesso aos órgãos e agentes da administração municipal. Ainda assim, a distribuição das respostas está distante de um quadro de completo predomínio do governismo, da cooptação e da subordinação do Legislativo ao Executivo, como parece sugerir boa parte da literatura. Há uma parte não desprezível de vereadores que acredita que é possível realizar seu 
trabalho independentemente de sua posição em relação ao prefeito e que afirma que a independência entre os poderes possui alguma eficácia prática para além da letra da lei.

Em uma questão mais específica sobre o papel dos vereadores em relação ao prefeito, buscamos testar a hipótese "vereador-ouvidor", sugerida por D Ávila Filho, Lima e Jorge (2014). Estudando o significado das indicações na atividade representativa municipal, os autores afirmam que esse mecanismo demonstra uma atuação do vereador como uma espécie de ouvidor do município, aquele que, por sua penetração nos bairros e comunidades, teria condições de identificar, para a administração, os principais problemas e demandas a serem atendidos e solucionados. Com isso, os autores colocam em relevo o papel informacional desempenhado pelo vereador em vez de simplesmente rotulá-los de assistencialistas e considerar suas ações como sendo de baixa relevância.

Os dados do survey (Tabela 6) corroboram a relevância dessa tese, já que 56\% afirmaram que o principal papel do vereador em relação ao prefeito é "ajudar a identificar e a solucionar os problemas do município". Nos três tipos de municípios, essa alternativa foi mais frequente entre os vereadores governistas, especialmente nos municípios pequenos e médios. O percentual que destacou o papel de fiscalização e controle não foi nada desprezível, representando $43,8 \%$ do total da amostra. A função de fiscalização foi mais frequente nas respostas dos vereadores não governistas dos municípios médios e grandes. Mas apenas nos municípios pequenos e médios a diferença entre governistas e não governistas apresentou significância estatística.

Tabela 6

Principal função do vereador em relação ao prefeito, por porte do município e posição em relação ao prefeito (\%)

\begin{tabular}{|c|c|c|c|}
\hline & & $\begin{array}{c}\text { Fiscalizar e controlar } \\
\text { as suas ações }\end{array}$ & $\begin{array}{c}\text { Ajudar a } \\
\text { identificar e a } \\
\text { solucionar os } \\
\text { problemas do } \\
\text { município }\end{array}$ \\
\hline \multirow{2}{*}{ Pequeno } & Governo & 31,0 & 69,0 \\
\hline & Oposição/independente & 49,1 & 50,9 \\
\hline \multirow{2}{*}{ Médio } & Governo & 31,4 & 68,6 \\
\hline & Oposição/independente & 65,9 & 34,1 \\
\hline \multirow{2}{*}{ Grande } & Governo & 42,0 & 58,0 \\
\hline & Oposição/independente & 63,6 & 34,1 \\
\hline Total & & 43,8 & 56,0 \\
\hline
\end{tabular}

Fonte: Elaboração própria com base em Nepol/PPGCSO/UFJF (2015).

Nota: Pearson's chi-square test $-\mathrm{p}$-value municípios pequenos $=, 004$. Pearson's chi-square test $-p$ value municípios médios $=, 003$. Pearson's chi-square test $-p$-value municípios grandes $=, 026$

\section{Definição da agenda e processo decisório}

A maior parte das análises sobre as relações entre Executivo e Legislativo e a relevância de cada um dos poderes no processo legislativo baseiam-se em indicadores 
objetivos de comportamento, como a taxa de sucesso e a taxa de dominância que indicam, respectivamente, o êxito de cada ator em ver os projetos de sua iniciativa transformados em lei e a participação de cada poder no total de leis produzidas. As altas taxas de dominância e de sucesso registradas para o Poder Executivo federal, pelo menos até o início dos anos 2000 (Almeida, 2018), costumam ser interpretadas como resultado dos poderes de agenda do presidente, isto é, sua capacidade de controlar o que será decidido e quando (Figueiredo e Limongi, 1999).

Em nossa análise, não dispomos de dados objetivos de produção legislativa para fazer afirmações cabais a respeito do controle da agenda, dominância ou sucesso de cada ator. Nossos dados de opinião, contudo, sugerem que, se o prefeito concentra poderes de agenda, isso se traduz em influência no processo legislativo municipal, e essa influência se materializa de forma indireta. Perguntamos aos vereadores "o que influenciava mais a tomada de decisões na câmara municipal". Os Gráficos 3 e 4 apresentam a distribuição das respostas por porte do município e por posição em relação ao governo:

\section{Gráfico 3}

O que mais influencia a tomada de decisões na câmara municipal? Por porte do município (\%)

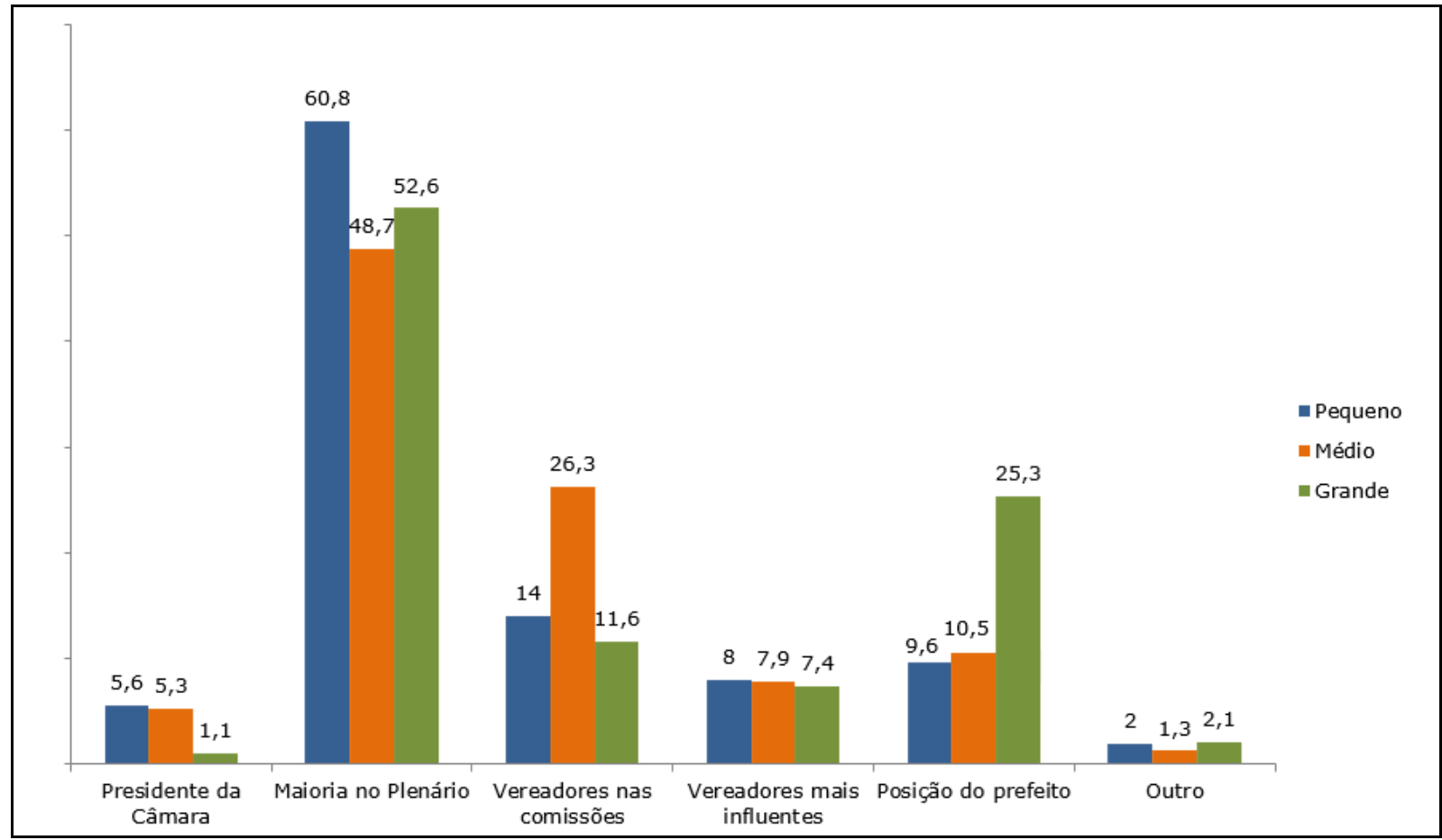

Fonte: Elaboração própria com base em Nepol/PPGCSO/UFJF (2015).

Nota: Pearson's chi-square test $-\mathrm{p}$-value $=, 004$. 
Gráfico 4

O que mais influencia a tomada de decisões na câmara municipal? Por posição em relação ao governo (\%)

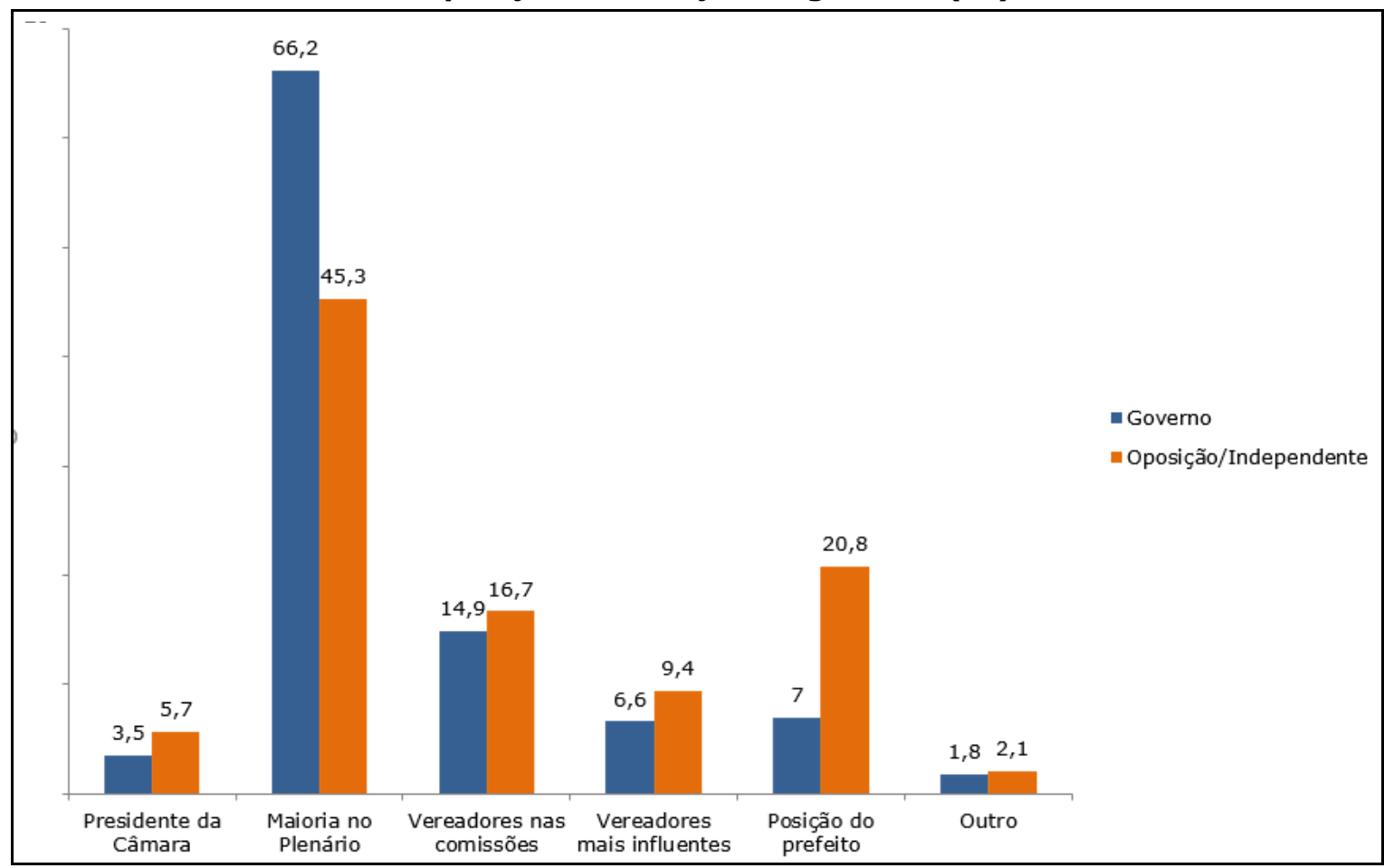

Fonte: Elaboração própria com base em Nepol/PPGCSO/UFJF (2015).

Nota: Pearson's chi-square test $-\mathrm{p}$-value $=, 000$

Observamos que, apesar de reconhecerem nas demais questões a importância de uma relação próxima com o prefeito, nos três tipos de municípios, a maior parte dos vereadores afirmou que o que mais influencia a tomada de decisões na câmara é "a posição da maioria dos vereadores em plenário", seguida do "trabalho dos vereadores nas comissões". No cômputo geral, a posição do prefeito apareceu somente em terceiro lugar. A exceção ficou por conta dos vereadores dos municípios grandes, entre os quais a posição do prefeito foi assinalada por um quarto dos entrevistados; e os vereadores de oposição, entre os quais a alternativa ficou em segundo lugar. Esse resultado desafia a ideia de um total predomínio do Executivo e de sua agenda sobre as câmaras municipais dos municípios pequenos, mostrando que a maior fragilidade institucional das últimas e sua dependência em relação aos recursos controlados pelo prefeito não se traduzem, diretamente, em controle da agenda legislativa pelo Executivo.

Os dados expostos até aqui, embora problematizem a tese do predomínio do governismo no nível municipal, deixam clara a importância do prefeito como ator político local. Se boa parte dos vereadores apoia o prefeito, beneficiam-se desse apoio e justificam sua atuação como uma forma de "ajudar" o Poder Executivo a resolver os 
problemas do município, isso não reduziria sua independência? Não minimizaria seu papel de controle do Executivo? Não contrariaria o próprio princípio de independência entre os poderes, que está na base do presidencialismo? Para tentar iluminar essas questões, na próxima subseção, investigaremos mais a fundo a frequência de mobilização, pelos vereadores, de uma série de mecanismos e instrumentos de fiscalização presentes no nível municipal.

\section{Controle e fiscalização do Executivo}

Uma visão disseminada na literatura é que, no nível local, a atividade de fiscalização do prefeito seria negligenciada pelos vereadores em favor de outras atividades mais valorizadas e tangíveis para os eleitores (Andrade, 1998; Neto, 2003). A oposição, que, em tese, teria os maiores incentivos para as atividades de controle e fiscalização, devido à tendência geral para a adesão ao governo, ficaria minguada e enfraquecida, sem o número de votos necessário para mobilizar os mecanismos constitucionais e regimentais de controle. Nesta subseção, buscamos examinar a consistência dessa visão focando as percepções, opiniões e atitudes dos vereadores entrevistados no que se refere à fiscalização do prefeito.

Na subseção anterior (Tabela 6), mostramos que uma parcela não desprezível de vereadores $(43,8 \%)$ afirmou que seu principal papel em relação ao prefeito é "fiscalizar e controlar" suas ações. A fiscalização recebeu maior destaque entre os vereadores não governistas dos municípios grandes $(63,6 \%)$ e médios $(65,9 \%)$. Em uma questão anterior, mais genérica, havíamos perguntado aos vereadores à qual função eles davam maior importância no exercício do mandato. Novamente, a fiscalização apareceu em segundo lugar, com quase um terço das respostas, atrás, apenas, de "resolver os problemas do município", sendo mais frequente nos municípios grandes (Tabela 7). Considerando o que afirma a literatura, é surpreendente que quase um terço dos vereadores tenha destacado a fiscalização como atividade mais importante. Entre os que se declararam de oposição e independentes, a fiscalização apareceu em primeiro lugar como função mais importante (Tabela 8 ). Tanto em relação ao porte quanto em relação à posição do vereador, as diferenças revelaram-se estatisticamente significativas. 
Tabela 7

Função a que dá mais importância por porte do município (\%)

\begin{tabular}{|l|c|c|c|c|c|}
\hline & $\begin{array}{c}\text { Elaborar } \\
\text { leis }\end{array}$ & $\begin{array}{c}\text { Resolver } \\
\text { problemas do } \\
\text { município }\end{array}$ & $\begin{array}{c}\text { Resolver } \\
\text { problemas do } \\
\text { bairro/distrito/ } \\
\text { região }\end{array}$ & $\begin{array}{c}\text { Fiscalizar } \\
\text { prefeito }\end{array}$ & $\begin{array}{c}\text { Propor } \\
\text { emendas ao } \\
\text { orçamento } \\
\text { Outra }\end{array}$ \\
\hline Pequeno & 15,5 & 46,2 & 10,0 & 25,9 & 2,4 \\
\hline Médio & 17,1 & 46,1 & 7,9 & 27,6 & 0,0 \\
\hline Grande & 24,2 & 22,1 & 13,7 & 40,0 & 0,0 \\
\hline Total & 17,8 & 40,8 & 10,4 & 29,4 & 0,0 \\
\hline
\end{tabular}

Fonte: Elaboração própria com base em Nepol/PPGCSO/UFJF (2015).

Nota: Pearson's chi-square test $-\mathrm{p}$-value $=, 002$.

Tabela 8

Função a que dá mais importância por posição em relação ao prefeito (\%)

\begin{tabular}{|l|c|c|c|c|c|}
\hline & $\begin{array}{c}\text { Elaborar } \\
\text { leis }\end{array}$ & $\begin{array}{c}\text { Resolver } \\
\text { problemas do } \\
\text { município }\end{array}$ & $\begin{array}{c}\text { Resolver } \\
\text { problemas do } \\
\text { bairro/distrito/ } \\
\text { região }\end{array}$ & $\begin{array}{c}\text { Fiscalizar } \\
\text { prefeito }\end{array}$ & $\begin{array}{c}\text { Propor } \\
\text { emendas ao } \\
\text { orçamento } \\
\text { Outra }\end{array}$ \\
\hline Governo & 18,9 & 45,6 & 12,7 & 21,5 & 1,3 \\
\hline $\begin{array}{l}\text { Oposição/ } \\
\text { Independente }\end{array}$ & 16,1 & 35,2 & 7,8 & 38,9 & 1,6 \\
\hline Total & 17,6 & 40,9 & 10,5 & 29,5 & 0,5 \\
\hline
\end{tabular}

Fonte: Elaboração própria com base em Nepol/PPGCSO/UFJF (2015).

Nota: Pearson's chi-square test $-\mathrm{p}$-value $=, 003$.

Em outras questões, buscamos identificar as formas pelas quais os vereadores exercem a fiscalização. Perguntamos a eles com que frequência realizaram várias atividades destinadas a fiscalizar e controlar o prefeito. A Tabela 9 apresenta a distribuição das respostas por porte do município e posição em relação ao prefeito. Ela nos permite identificar os mecanismos mais e menos utilizados, mas não dispomos de informação sobre o êxito dos vereadores na sua utilização: 
Tabela 9

Mobilizou algumas ou muitas vezes os seguintes mecanismos de fiscalização? Por porte do município e posição em relação ao prefeito $(\%)^{15}$

\begin{tabular}{|c|c|c|c|c|}
\hline & $\begin{array}{l}\text { Porte do } \\
\text { município }\end{array}$ & Governo & $\begin{array}{c}\text { Oposição/ } \\
\text { independente }\end{array}$ & Total \\
\hline \multirow{3}{*}{$\begin{array}{l}\text { 1. Pedido para comparecimento } \\
\text { do prefeito ou secretários na } \\
\text { Câmara }\end{array}$} & Pequeno & 45,1 & 59,3 & \multirow{3}{*}{51,2} \\
\hline & Médio & 34,3 & 68,3 & \\
\hline & Grande & 44,0 & 56,8 & \\
\hline \multirow{3}{*}{ 2. Instalação de CPI } & Pequeno & 3,5 & 9,3 & \multirow{3}{*}{7,6} \\
\hline & Médio & 2,9 & 9,8 & \\
\hline & Grande & 6,0 & 20,5 & \\
\hline \multirow{3}{*}{$\begin{array}{l}\text { 3. Pedido de informações ao } \\
\text { prefeito ou secretários }\end{array}$} & Pequeno & 54,2 & 74,8 & \multirow{3}{*}{69,6} \\
\hline & Médio & 68,6 & 92,5 & \\
\hline & Grande & 76,0 & 79,5 & \\
\hline \multirow{3}{*}{$\begin{array}{l}\text { 4. Denúncias sobre ações e faltas } \\
\text { da prefeitura na imprensa local }\end{array}$} & Pequeno & 5,6 & 16,7 & \multirow{3}{*}{22,9} \\
\hline & Médio & 8,6 & 56,1 & \\
\hline & Grande & 26,0 & 70,5 & \\
\hline \multirow{3}{*}{$\begin{array}{l}\text { 5. Falar sobre ações e faltas da } \\
\text { prefeitura na tribuna do plenário }\end{array}$} & Pequeno & 48,6 & 81,5 & \multirow{3}{*}{69,3} \\
\hline & Médio & 71,4 & 95,1 & \\
\hline & Grande & 62,0 & 88,6 & \\
\hline
\end{tabular}

Fonte: Elaboração própria com base em Nepol/PPGCSO/UFJF (2015).

A Tabela 9 mostra que, de modo geral, independentemente do porte do município e da posição em relação ao governo, os mecanismos mais mobilizados pelos vereadores foram os pedidos de informação $(69,6 \%)$ e a fala no plenário $(69,3 \%)$, que, provavelmente, implicam menores custos para os legisladores. Os mecanismos menos utilizados foram a solicitação de instalação da CPI (apenas 7,6\% afirmaram ter feito algumas ou muitas vezes), as denúncias na imprensa local $(22,9 \%)$ e os pedidos de comparecimento de autoridades da administração municipal na câmara $(51,2 \%)$. A convocação de uma CPI se aplica a casos mais extremos e, geralmente, exige requisitos mais difíceis de cumprir, daí a menor frequência de seu uso. As denúncias na imprensa e os pedidos de comparecimento podem ser vistos como ações mais incisivas, de maior enfrentamento, com maior potencial de exposição das falhas da administração municipal.

Nos municípios pequenos e grandes, em relação a todos os itens, o uso dos mecanismos foi mais frequente entre os vereadores de oposição e independentes. As diferenças entre governistas e não governistas foram estatisticamente significativas, segundo o resultado do teste qui-quadrado ( $\mathrm{p}$ valor $=, 003$ para CPI e ,000 para todos os demais itens), independentemente do porte do município. Esse dado corrobora a ideia de que são os vereadores de oposição os que se mobilizam mais para a fiscalização do Executivo.

15 Nos itens 1 e 3, perguntamos aos vereadores se eles solicitaram comparecimento e informação por escrito. 
A convergência na ordem em que os vereadores de oposição e independentes mobilizaram cada recurso em municípios de diferentes portes populacionais pode sugerir uma semelhança em termos de custos, benefícios e recompensas associados a cada tipo de mecanismo. Foi em relação à mobilização da imprensa que observamos a maior diferença percentual entre os vereadores de oposição/independentes em função do porte: enquanto $70,5 \%$ dos vereadores de oposição e/ou independentes afirmaram ter utilizado algumas ou muitas vezes esse mecanismo nos municípios grandes, nos pequenos, apenas $16,7 \%$ dos que não apoiaram o governo assinalaram ter usado esse expediente.

Não dispomos de informações detalhadas sobre as regras para utilização de cada um desses mecanismos nos 44 municípios pesquisados, nem sobre o grau de êxito dos vereadores. Dessa forma, não temos como afirmar se a sua maior utilização pela oposição expressa a eficácia, de fato, desses mecanismos em expor e fazer pressão sobre o prefeito e/ou ampliar os níveis de transparência e prestação de contas; ou se, simplesmente, os vereadores mobilizam os instrumentos como forma de sinalizar esforços para os eleitores, mas sem efeitos práticos. De toda forma, as diferenças consistentes entre governo e oposição no uso dos instrumentos problematizam a noção de que as câmaras municipais seriam, em sua grande maioria, subservientes e negligentes em relação ao controle do Executivo.

Para uma apreciação mais concisa dos dados, construímos um índice de disposição para a fiscalização (DISP_FISC) a partir das respostas dos vereadores aos cinco itens (excetuando visitas a órgãos públicos) (Gráfico 5). O índice variou de 0, para quem afirmou nunca ter mobilizado nenhum mecanismo, a 15, para quem afirmou ter mobilizado muitas vezes todos eles, com média de 5,96 e desvio-padrão de 3,342. Cerca de metade dos entrevistados (54,2\%) situou-se até o ponto 6 do índice, bem próximo da média. A outra metade se distribuiu dos pontos 7 ao 15, com uma menor concentração nos escores mais altos (apenas $14 \%$ pontuaram de 10 a 15 ). 
Gráfico 5

Distribuição dos vereadores no índice de disposição para a fiscalização (N)

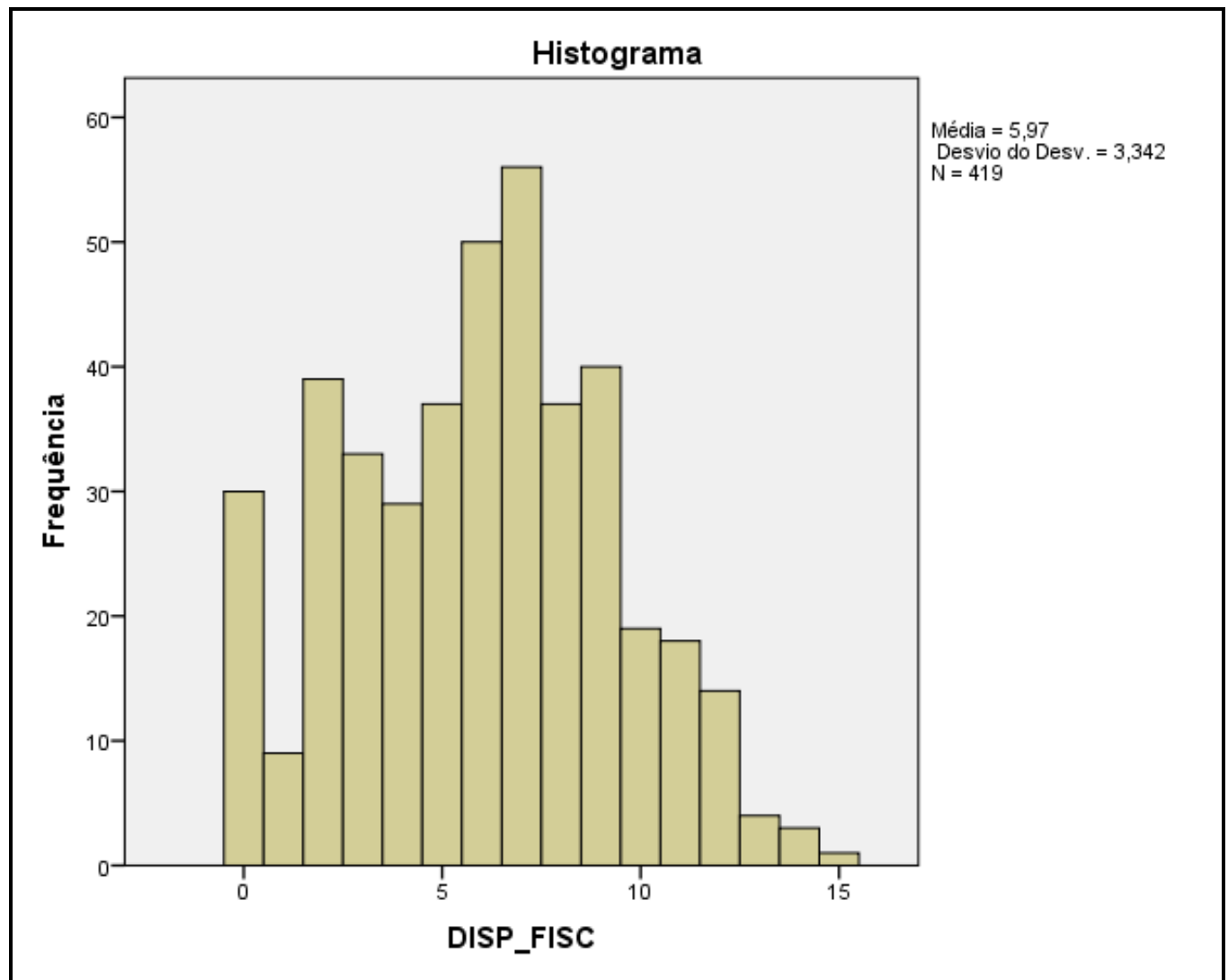

Fonte: Elaboração própria com base em Nepol/PPGCSO/UFJF (2015).

O Gráfico 6 deixa claro que a disposição para a fiscalização é maior entre os vereadores que não apoiam o governo. Entre estes, a pontuação média no índice foi de 7,45 , contra 4,75 dos vereadores que apoiam o prefeito. 
Gráfico 6

Disposição para a fscalização por posição em relação ao prefeito

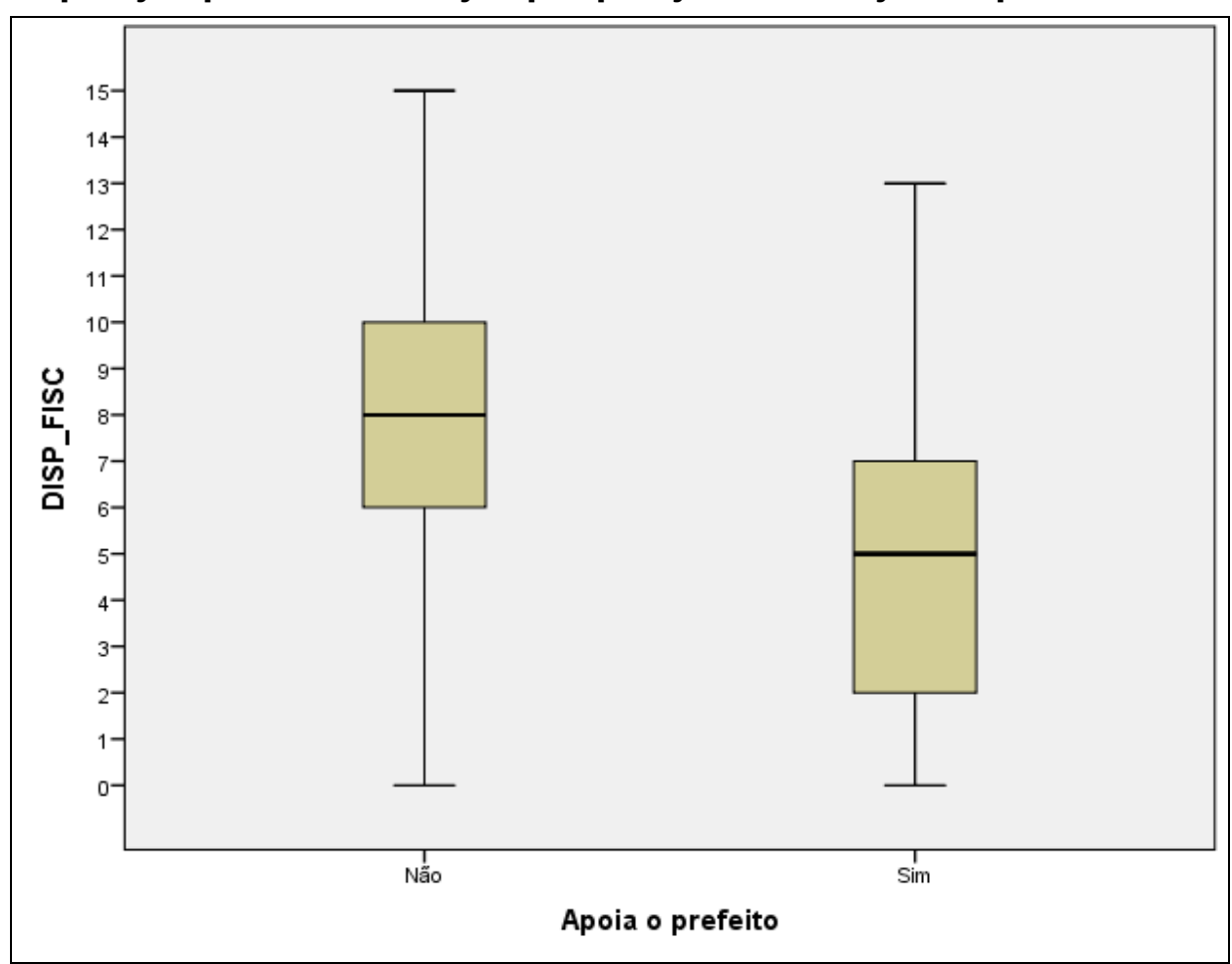

Fonte: Elaboração própria com base em Nepol/PPGCSO/UFJF (2015).

Como já sugerido, os não governistas apresentaram maior pontuação no índice de disposição para a fiscalização em comparação com os governistas, e o teste Anova (Tabela 10) mostra que a diferença entre os grupos é estatisticamente significativa ao nível de 0,01:

\section{Tabela 10}

Teste Anova comparando a pontuação de governistas e não-governistas no Índice de Disposição para a Fiscalização

\begin{tabular}{|l|c|c|c|c|c|}
\hline & $\begin{array}{c}\text { Soma dos } \\
\text { quadrados }\end{array}$ & $\begin{array}{c}\text { Graus de } \\
\text { liberdade }\end{array}$ & $\begin{array}{c}\text { Quadrado } \\
\text { médio }\end{array}$ & F & Sig. \\
\hline Entre grupos & 753,987 & 1 & 753,987 & 80,843 &, 000 \\
\hline Nos grupos & 3879,860 & 416 & 9,327 & & \\
\hline Total & 4633,847 & 417 & & & \\
\hline
\end{tabular}

Fonte: Elaboração própria com base em Nepol/PPGCSO/UFJF (2015) 
Gráfico 7

Disposição para a fiscalização por porte do município

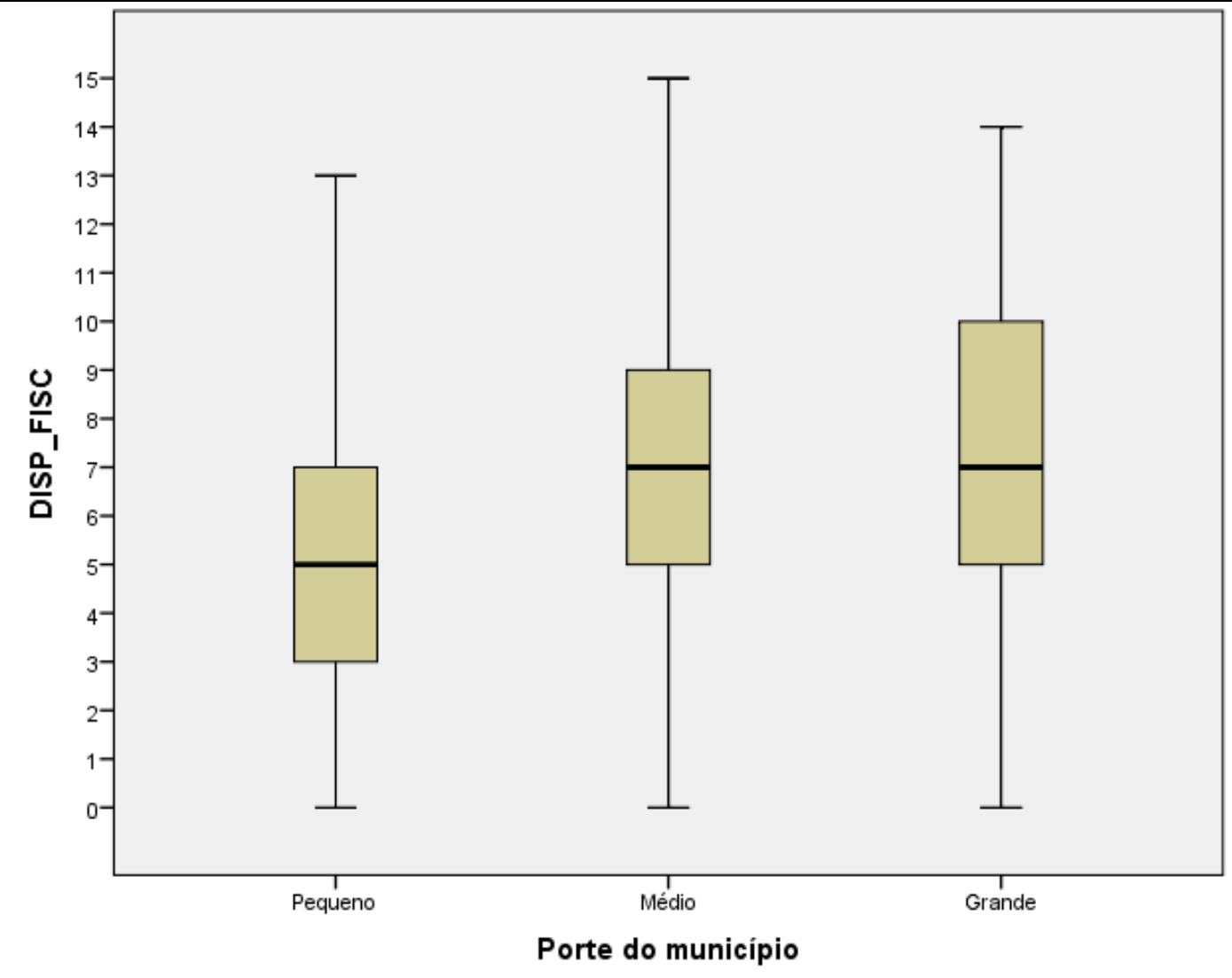

Fonte: Elaboração própria com base em Nepol/PPGCSO/UFJF (2015).

O Gráfico 7 mostra que há maior disposição para a fiscalização entre vereadores de municípios médios e grandes em comparação com os pequenos. O resultado do teste Anova (Tabela 11) expressa diferença significativa na comparação das médias entre, pelo menos, dois grupos de municípios. A Tabela 12 mostra os resultados de um teste posthoc Anova Bonferroni, que realiza comparações múltiplas entre as médias e permite analisar a diferença entre os grupos de municípios. É possível observar que a diferença média na disposição para a fiscalização é estatisticamente significativa entre os vereadores dos municípios pequenos em comparação com os dos municípios médios e grandes ao nível de 0,01. 
Tabela 11

Resultado de um teste Anova comparando a pontuação dos vereadores no índice de disposição para a fiscalização por porte do município

\begin{tabular}{|l|c|c|c|c|c|}
\hline & $\begin{array}{c}\text { Soma dos } \\
\text { quadrados }\end{array}$ & $\begin{array}{c}\text { Graus de } \\
\text { liberdade }\end{array}$ & $\begin{array}{c}\text { Quadrado } \\
\text { médio }\end{array}$ & F & Sig. \\
\hline Entre grupos & 362,024 & 2 & 181,012 & 17,481 &, 000 \\
\hline Nos grupos & 4307,508 & 416 & 10,355 & & \\
\hline Total & 4669,532 & 418 & & & \\
\hline $\mathrm{N}=422$ & & & & & \\
\hline
\end{tabular}

Fonte: Elaboração própria com base em Nepol/PPGCSO/UFJF (2015).

Tabela 12

Resultados do teste post-hoc Anova - Bonferroni

\begin{tabular}{|l|c|c|c|c|c|c|}
\hline \multicolumn{1}{|c|}{} & \multicolumn{2}{c|}{$\begin{array}{c}\text { Intervalo de confiança } \\
\text { de } 95 \%\end{array}$} \\
\hline \multirow{2}{*}{ Pequeno } & $\begin{array}{c}\text { Diferença } \\
\text { média }\end{array}$ & $\begin{array}{c}\text { Erro- } \\
\text { padrão }\end{array}$ & Sig. & $\begin{array}{c}\text { Limite } \\
\text { inferior }\end{array}$ & $\begin{array}{c}\text { Limite } \\
\text { superior }\end{array}$ \\
\cline { 2 - 7 } & Médio & $-1,783^{*}$ &, 424 &, 000 & $-3,03$ &,- 53 \\
\hline \multirow{2}{*}{ Médio } & Grande & $-1,977^{*}$ &, 389 &, 000 & $-3,13$ &,- 83 \\
\cline { 2 - 7 } & Pequeno & $1,783^{*}$ &, 424 &, 000 &, 53 & 3,03 \\
\hline \multirow{2}{*}{ Grande } & Grande &,- 194 &, 498 & 1,000 & $-1,67$ & 1,28 \\
\cline { 2 - 7 } & Pequeno & $1,977^{*}$ &, 389 &, 000 &, 83 & 3,13 \\
\hline
\end{tabular}

Fonte: Elaboração própria com base em Nepol/PPGCSO/UFJF (2015).

* Significativo ao nível de 0,01.

Em conjunto, os dados analisados nesta subseção contribuem para problematizar a tese de que os vereadores negligenciam a função de fiscalizar o prefeito. Ao contrário, uma boa parte deles afirma ter mobilizado uma variedade de mecanismos de controle. E a disposição para fazê-lo é maior entre os vereadores que não apoiam o governo, dos municípios médios e grandes. Considerando a centralidade do Executivo no nível municipal, a fragilidade institucional de boa parte das câmaras municipais no Brasil e a falta de visibilidade das ações de fiscalização perante a opinião pública, o que explicaria a decisão de um vereador de se manter na oposição ou independente? Em outras palavras, por que alguns vereadores resistem à tentação de apoiar o governo quando, segundo a percepção da maioria deles, isso traz resultados positivos para os legisladores? Já vimos que, entre os entrevistados, 48 vereadores pertenciam ao partido do candidato que ficou em segundo lugar e que, destes, $13(27,1 \%)$ mudaram de lado e aderiram à situação. A decisão da maioria de permanecer na oposição pode significar uma aposta em uma possibilidade de vitória na rodada seguinte. 
Outra hipótese é que a permanência na oposição seria menos penosa para vereadores com acesso a fontes alternativas de recursos. Buscamos verificar se a propensão a se alinhar ao prefeito seria menor entre vereadores alinhados ao governo estadual e/ou federal e que afirmaram possuir alianças/contato/proximidade com deputados. A análise mostrou que estar filiado a um partido que compunha a coalizão da presidente não fez diferença para um vereador apoiar ou não o prefeito. O percentual que declarou que não apoiou o prefeito é muito semelhante entre os vereadores de partidos da coalizão $(46,2 \%)$ e os vereadores dos demais partidos $(45,5 \%)$. Entre os vereadores filiados a partidos que faziam parte da coalizão do governador do estado, foi ligeiramente maior o percentual que declarou não apoiar o prefeito $(49,1 \%)$ em comparação com os vereadores cujos partidos não faziam parte da coalizão $(44,6 \%)$, mas as diferenças entre os grupos não foram estatisticamente significativas. Entre os vereadores que tinham aliança, proximidade e/ou contato com deputados, é menor o percentual que afirmou apoiar o prefeito: $49,7 \%$ entre os que possuíam aliança contra $58,0 \%$, que não possuíam, mas a diferença não foi estatisticamente significativa. A explicação talvez esteja no fato de que, como sugere a literatura (Ames, 2001; Carvalho, 2003), são os prefeitos, enquanto figuras mais notáveis no município, e não os vereadores, os beneficiários diretos da proximidade e do alinhamento com representantes nos níveis estadual e federal.

Além disso, é importante considerar um elemento conjuntural. À época das entrevistas, o Partido dos Trabalhadores estava à frente dos governos estadual e federal, e ainda assim o percentual de vereadores que se declararam governistas foi menor em relação aos prefeitos do PT $(43,6 \%)$ em comparação com prefeitos de outros partidos $(57,2 \%)$, com diferença estatisticamente significativa entre os grupos (ao nível de 0,05 ). No período de realização das entrevistas (de fevereiro a novembro de 2015), a Operação Lava Jato estava a todo vapor, o PT era o líder de rejeição entre os partidos e o governo Dilma amargava altos níveis de reprovação ${ }^{16}$. Um mês após o término das entrevistas, o pedido de impeachment contra a presidente foi aceito na Câmara dos Deputados. Logo, é muito provável que os desgastes envolvendo o PT no plano federal tenham contribuído para que, nessa ocasião, o alinhamento dos prefeitos com os governos estadual e federal não tornasse o governismo mais atraente para os vereadores, mas o contrário. Vale registrar que, dos nove municípios da amostra administrados pelo PT, em apenas dois o partido saiu vitorioso nas eleições de 2016.

16 Disponível em: <http://g1.globo.com/politica/noticia/2015/08/71-reprovam-governo-dilma-dizdatafolha.html e https://valor.globo.com/politica/noticia/2015/11/08/pt-lidera-rejeicao-a-partidos-com-38em-pesquisa-ibope-diz-jornal.ghtml>. Acesso em: 10 nov. 2020. 


\section{Considerações finais}

Neste artigo, nosso objetivo foi analisar o governismo no nível municipal por meio de dados de opinião coletados junto a vereadores de 44 municípios de Minas Gerais. Partindo do conhecimento acumulado sobre a relação entre Executivo e Legislativo no nível municipal, buscamos verificar a extensão do governismo, entendido como uma tendência dos vereadores de se alinharem ao prefeito e de negligenciarem suas funções de fiscalização e controle. Além disso, investigamos a forma como os prefeitos constroem suas bases de apoio, seu grau de influência sobre o processo decisório e o comportamento declarado dos vereadores no que se refere ao uso de mecanismos de fiscalização do Executivo.

A análise dos dados revelou que o governismo está longe de ser a regra entre os vereadores analisados e que há uma parcela significativa de parlamentares dispostos a permanecer na oposição ou como independentes. Dessa forma, sugere que as mudanças trazidas pela Constituição de 1988 com o consequente fortalecimento das câmaras municipais não podem ser tratadas como meras formalidades e que a reprodução do presidencialismo no nível municipal parece, de fato, colocar a serviço dos cidadãos dois agentes com algum grau de independência entre si. Ainda que haja concentração de prerrogativas e recursos nas mãos dos prefeitos e que as câmaras municipais da maioria dos municípios do país exibam baixo grau de desenvolvimento institucional, os vereadores não se encontram totalmente privados de recursos e de possibilidades para uma ação independente do Executivo.

O cruzamento dos dados de opinião com os dados sobre coligações mostra que há boa dose de continuidade entre o processo de montagem das chapas e a construção de uma maioria de apoio após as eleições. E que, em algum grau, o partido importa na definição do apoio e na decisão de aderir ou não ao governo. A análise também mostrou que o processo de construção de uma maioria de apoio ao prefeito envolve diferentes estratégias e recursos, incluindo persuasão, diálogo, troca de favores e incentivos coletivos, e que as percepções sobre esse processo são diferentes entre os vereadores governistas e não governistas.

Na tentativa de captar a importância da atuação de líderes parlamentares - um ingrediente fundamental nas explicações das relações entre Executivo e Legislativo em nível nacional -, foi possível identificar algumas singularidades do processo político no nível municipal. Apesar de a maioria dos vereadores afirmar que há distribuição desigual de poder entre os parlamentares, com atuação destacada de certos vereadores, os dados mostraram que a posição de liderança não decorre de fatores endógenos à câmara, que remetem aos incentivos internos à organização legislativa. Aqui encontramos um elemento que corrobora a tese do governismo, já que a manutenção de boas relações com o prefeito foi o elemento mais destacado, ao lado do número de mandatos. 
Outro elemento favorável ao governismo diz respeito ao tratamento diferenciado dado pelo prefeito e pelos agentes públicos aos vereadores da base de apoio. Três quartos dos vereadores foram claros em afirmar que apoiar ou não o prefeito tem impactos para o vereador. Impactos que podem ser positivos - ter mais acesso, atenção, visibilidade, atendimento facilitado - ou negativos - sofrer perseguição e ser privado de recursos. Os dados parecem corroborar a tese de que o alinhamento ao prefeito é fundamental para os vereadores serem capazes de atender seus eleitores e assegurar seu sucesso político e eleitoral. Ainda assim, consideramos que a distribuição das respostas está distante de um quadro de completo predomínio do governismo, da cooptação e da subordinação do Legislativo ao Executivo, como parece sugerir boa parte da literatura. Além disso, mostramos que a posição do prefeito em relação às matérias em apreciação na câmara é menos decisiva do que se poderia esperar, tendo mais peso entre os vereadores dos municípios pequenos.

Outras evidências que problematizam a tese de subserviência das câmaras aos prefeitos estão no percentual de vereadores que afirmaram que, no exercício de sua função, dão prioridade à fiscalização. Nos municípios grandes, essa foi a opção mais assinalada pelos vereadores. Nos municípios pequenos e médios, ela ficou atrás apenas de "resolver problemas do município". A frequência com que os vereadores mobilizaram mecanismos de fiscalização e controle - sobretudo os vereadores dos municípios médios e grandes que não apoiam o prefeito - é outra evidência de que aquela função não é completamente negligenciada pelos legisladores no nível local.

Não é possível desprezar a presença do governismo nos municípios e o fato de que, a cada dez vereadores que apoiavam o governo, três não pertenciam à coligação vencedora e foram incorporados à base após a eleição. Em câmaras muito pequenas, a incorporação de um único vereador pode ser suficiente para alterar todo o equilíbrio de forças, prover a maioria necessária ao prefeito e desidratar a oposição. O governismo, enquanto um padrão de relacionamento entre os poderes, parece ser uma realidade mais frequente nos municípios pequenos, como já tendia a sustentar parte da literatura. Nesses cenários, os cidadãos seriam mais dependentes dos recursos públicos - o poder público é o principal empregador e os recursos de programas sociais compõem parte importante da renda em circulação - e os vereadores seriam mais dependentes do Executivo para atender às demandas dos eleitores e, consequentemente, ampliar suas chances de reeleição.

Outros fatores que poderiam ajudar a explicar as variações no grau de adesão ao Executivo não se mostraram decisivos em uma análise preliminar. Verificamos não haver diferenças expressivas (ou estatisticamente significativas) no grau de apoio ao prefeito em função da competitividade eleitoral (margem de vitória do prefeito), da fragmentação parlamentar (medida pelo número efetivo de partidos da câmara) ou do status do prefeito (primeiro ou segundo mandato). Também é necessário investigar mais a fundo o efeito da pobreza sobre o governismo. Embora seja razoável esperar que menor 
desenvolvimento e maior pobreza aumentem a dependência em relação ao Executivo e, logo, a tendência para o governismo, os dados do survey não confirmaram essa intuição, uma vez que a proporção de vereadores governistas foi praticamente a mesma nos municípios ricos e pobres. O desenvolvimento institucional do Legislativo municipal mensurado através das percepções dos vereadores sobre a qualidade da estrutura física e dos recursos materiais, humanos e tecnológicos das câmaras - também não mostrou associação com o grau de apoio ao prefeito. Por último, verificamos não haver uma maior tendência ao governismo no caso de prefeitos do PT, partido que à época da realização das entrevistas com os vereadores estava à frente dos governos federal e estadual.

Mesmo se tratando de dados que não podem ser generalizados para o conjunto dos municípios ou dos vereadores brasileiros, as evidências reunidas e apresentadas neste artigo sugerem maior cautela em generalizações que tendem a enfatizar o governismo como um padrão dominante de relacionamento entre prefeitos e vereadores. Uma conclusão convergente com a que encontramos nos estudos sobre as relações entre Executivo e Legislativo no nível estadual, os quais mostram que, apesar das semelhanças do ponto de vista institucional, as diferenças no tocante à estruturação do sistema partidário e ao grau de competição política estadual impactam o relacionamento entre os poderes (Santos, 2001; Ricci e Tomio, 2018).

Por essas razões, acreditamos que uma melhor compreensão das variações entre os municípios no que tange à extensão do governismo deve ser buscada na análise das particularidades da competição política local, incluindo a configuração das forças políticas locais, o histórico da competição e as clivagens partidárias, de grupos, facções e famílias. Análises longitudinais que combinem diferentes tipos de evidências também são necessárias para avançar em questões que permanecem em aberto. Entre elas, compreender as motivações dos vereadores que se dispõem a se manter na oposição ou como independentes e analisar o êxito dos legisladores em monitorar e responsabilizar o prefeito e as autoridades da administração municipal por suas ações e omissões. O cotejamento dos dados de opinião com indicadores mais objetivos de comportamento também é fundamental para avaliar a consistência de algumas conclusões.

\section{Referências bibliográficas}

ABRÚcio, F. O ultrapresidencialismo estadual. In: ANDRADE, R. C. (org.). Processo de governo no município e no estado. São Paulo: Edusp/Fapesp, p. 87-116, 1998.

ALMEIDA, A.; LOPEZ, F. G. "Representação política local: padrões de atuação dos vereadores em quatro cidades mineiras". Texto para discussão, Ipea, Brasília, nº 1.625, p. 44, jun. 2011.

ALMEIDA, P. C. "Processos de construção de lugares de memória da resistência em Salvador: projetos, disputas e assimetrias". Tese de Doutorado em História, Políticas e Bens Culturais. Fundação Getulio Vargas, São Paulo, 2018.

AMES, B. The deadlock of democracy in Brazil. Ann Arbor: Michigan University Press, 2001. 
AndRADE, R. C. Processos decisórios na Câmara dos Vereadores e na Assembleia Legislativa de São Paulo. In: ANDRADE, R. C. (org.). Processo de governo no município e no estado. São Paulo: Edusp/Fapesp, p. 11-40, 1998.

BARBosA, A. R. "Relação Executivo-Legislativo municipal brasileiro: produção dos projetos de leis em Salvador". Cadernos de Estudos Sociais e Politicos, vol. 4, no 7, p. 84-113, 2015.

CAETANo, B. "Executivo e Legislativo na esfera local: o caso do município de São Paulo". Dissertação de Mestrado em Ciência Política, Universidade de São Paulo, São Paulo, 2004.

. "Executivo e Legislativo na esfera local". Novos Estudos Cebrap, no 71, mar. 2005.

CAREY, J. M.; ShugaRT, M. "Poder de decreto: chamando os tanques ou usando a caneta?". Revista Brasileira de Ciências Sociais, vol. 13, no 37, p. 149-184, 1998.

CARVAlHo, N. R. E no início eram as bases: geografia política do voto e comportamento legislativo no Brasil. Rio de Janeiro: Revan, 2003.

Couto, C. G. Negociação, decisão e governo: padrões interativos na relação Executivo-Legislativo e o caso paulistano. In: ANDRADE, R. C. (org.). Processo de governo no município e no estado. São Paulo: Edusp, p. 41-72, 1998.

Couto, C. G.; ABSHER-BelLon, G. L. "Imitação ou coerção? Constituições estaduais e centralização federativa no Brasil". Revista de Administração Pública, São Paulo, vol. 52, no 2, p. 321-344, 2018.

D’Ávila FILHO, P., et al. "Legislativo municipal e intermediação de interesses: notas de pesquisa". In: $4^{\circ}$ Encontro da ABCP, 2004.

D'Ávila FILHO, P. M.; LIMA, P. C.; JoRGE, V. L. Comportamento político e produção legislativa: padrões de emissão de indicações pelos vereadores cariocas. In: RocHA, M. M.; KERBAUY, M. T. M. (eds.). Eleições, partidos e representação política nos municípios brasileiros. Juiz de Fora: Editora UFJF, p. 191-214, 2014.

ERMACOVITCH, I. "A vereança somos nós? Reflexões sobre cultura política, representação e produção legislativa da Câmara Municipal de Porto Alegre". Monografia apresentada ao curso de Ciências Sociais, Universidade Federal do Rio Grande do Sul, Rio Grande do Sul, 2010.

FigueIREDo, A.; LIMONGI, F. Executivo e Legislativo na nova ordem constitucional. Rio de Janeiro: FGV, 1999.

GARCIA. J. "Executivo e Legislativo no âmbito municipal: a formação de gabinetes no município de São Paulo (1989-2012)". Dissertação de Mestrado em Administração Pública. Fundação Getulio Vargas, São Paulo, 2013.

Gomes, C. A. T. "Conexão eleitoral na cidade: geografia do voto e projetos de lei em Belo Horizonte (2001-2007)". Dissertação de Mestrado em Sociologia, Pontifícia Universidade Católica de Minas Gerais, Minas Gerais, 2009.

GrIN, E. J. "Executivo e Legislativo na cidade de São Paulo: coalizões políticas e o poder dos vereadores nos territórios". Revista Iberoamericana de Estudios Municipales, vol. 3, no 5, p. 65-94, 2012.

IBGE. Indicadores sociais municipais: uma análise dos resultados do universo do censo demográfico 2010. Instituto Brasileiro de Geografia e Estatística, 2010. Disponível em:

<https://biblioteca.ibge.gov.br/visualizacao/livros/liv54598.pdf>. Acesso em: 25 out. 2013.

KERBAUY, M. T. M. "As câmaras municipais brasileiras: perfil de carreira e percepção sobre o processo decisório local". Opinião Pública, Campinas, vol. XI, no 2, p. 337-365, out. 2005. 
KInzo, M. D. G. O quadro partidário na Constituinte. In: LAMOUnIER, B. (ed.). De Geisel a Collor - O balanço da transição. São Paulo: Idesp/Sumaré, 1990.

KuschniR, K. O cotidiano da política. Rio de Janeiro: Jorge Zahar, 2000.

LAMOUNIER, B. Presidente Prudente: o crescimento da oposição num reduto arenista. In: ReIS, F. (org.). Os partidos e o regime: a lógica do processo eleitoral brasileiro (online). Rio de Janeiro: Centro Edelstein de Pesquisa Social, p. 7-98, 2009 [1978].

LEAL, V. N. Coronelismo, enxada e voto: o município e o regime representativo no Brasil. São Paulo: Companhia das Letras, 2012 [1948].

LOPEZ, F. G. "A política cotidiana dos vereadores e as relações entre Executivo e Legislativo em âmbito municipal: o caso do município de Araruama". Revista de Sociologia e Política, Curitiba, no 22, p. 153-177, 2004.

LOPEZ, F.; ALmEIDA, A. "Legisladores, captadores e assistencialistas: a representação política no nível local". Revista de Sociologia e Política (online), vol. 25, nº 62, p. 157-181, 2017.

Melo, C. R. F. Migração partidária, estratégias de sobrevivência e governismo na Câmara dos Deputados (online), 2002. Disponível em: <https://www.anpocs.com/index.php/papers-26encontro/gt-23/gt08-19/4394-crmelo-migracao/file >. Acesso em: 11 nov. 2020.

Retirando as cadeiras do lugar. Migração partidária na Câmara dos Deputados (19852002). Belo Horizonte: Editora UFMG, 2004.

NEPOI/PPGCSO/UFJF. P. "Representação política no nível municipal no Brasil". Pesquisa desenvolvida no âmbito do Núcleo de Estudos sobre Política Local (Nepol). Programa de Pós-Graduação em Ciências Sociais da Universidade Federal de Juiz de Fora. Juiz de Fora, 2015.

Neto, J. O Legislativo e o poder local. In: Benevides, M. V., et al. (orgs.). Reforma política e cidadania. São Paulo: Perseu Abramo, p. 413-448, 2003.

O'DonNeLL, G. "Delegative democracy?". Journal of Democracy, vol. 51, p. 55-69, 1994.

PNUD. Programa das Nações Unidas para o Desenvolvimento. Atlas do Desenvolvimento Humano no Brasil, 2013. Disponível em: <http://www.atlasbrasil.org.br/>. Acesso em: 30 abr. 2013.

Power, T. J.; RodRigues-Silveira, R. "Mapping ideological preferences in Brazilian elections, 19942018: a municipal-level study". Brazilian Political Science Review, vol. 13, no 1, 2019.

PRAÇA, S.; GARCiA, J. "Formação de governo no nível municipal: o caso dos municípios paulistas". In: $35^{\circ}$ Encontro Anual da Anpocs. GT 10: Estudos Legislativos, 2011.

Pralon, E. M.; Ferreira, G. N. Centralidade da Câmara Municipal de São Paulo no processo decisório. In: ANDRADE, R. C. (org.). Processo de governo no município e no estado: uma análise a partir de São Paulo. São Paulo: USP, p. 73-86, 1998.

Ricci, P.; Tomio, F. R. L. "Governadores e assembleias legislativas: instituições e política nos estados brasileiros". Alameda, São Paulo, vol. 1, p. 9, 2018.

RoCHA, M. M.; SiLVA, B. S. "O poder de indicar: preferências legislativas de vereadores mineiros". Cadernos Adenauer xviii, no 2. Poder Legislativo sob múltiplos olhares. Rio de Janeiro: Fundação Konrad Adenauer, p. 185-208, jul. 2017.

SANTOS, F. "Partidos e comissões no presidencialismo de coalizão". Dados (online), vol. 45, n 2, p. 237-264, 2002. 
. (org.). O Poder Legislativo nos estados: diversidade e convergência. Rio de Janeiro: Editora FGV, 2001.

SiLVA, B. Produção legislativa e relações Executivo-Legislativo no nível local: uma análise das indicações e dos requerimentos na Câmara Municipal de Araraquara-SP. In: ROCHA, M.; KERBAUY, M. T. (orgs.). Eleições, partidos e representação política nos municípios brasileiros. Juiz de Fora: Editora UFJF, 2014.

Silva, B. S.; DANTAS, H. "Quem são eles? Identificando e caracterizando os vereadores brasileiros (2000-2016)". Anais do 90 Congresso Latino-Americano de Ciência Política (Alacip), p. 1-32, Montevidéu, 2017.

SILVA, P. "O pork barrel no Município de São Paulo: a produção legislativa dos vereadores paulistanos". Centro de Estudos da Metrópole (CEM). Texto para discussão no 011/2011, p. 1-25, 2011.

. "O Poder Legislativo municipal: estrutura, composição e produção". Dissertação de Mestrado. Programa de Pós-Graduação em Ciência Política. Universidade de São Paulo, São Paulo, 2014.

SNYDER, R. "Scaling down: the subnational comparative method". Studies in Comparative International Development, vol. 36, nº 1, p. 93-110, 2001.

TRANSPARÊnCIA Brasil. "Relatório da pesquisa do projeto Excelências". Porto Alegre, 2008.

Zucco, C. Poor voters vs poor places: persisting patterns in presidential elections in Brazil. Woodrow Wilson School. Princeton: Princeton University, 2010. Disponível em:

<http://centrodametropole.fflch.usp.br/sites/centrodametropole.fflch.usp.br/files/user_files/noticias/ ckeditor/003.2010-Zucco.pdf>. Acesso em: 5 nov. 2020.

\begin{abstract}
Local governism: Executive-Legislative relations in municipalities in the state of Minas Gerais

This article investigates the tendency of the local councilors to support the mayor and to pass the bills enacted by the municipal Executive without further considerations, usually called in Brazil as "governismo". It also investigates the incentives for this behavior and the strategies mobilized by the mayors to build support in the local council. The analysis was based on an unprecedented set of data resulting from a survey conducted with a sample of local councilors in Minas Gerais. The evidence gathered shows that the "governismo" is far less widespread than one might suppose and that there is an expressive number of councilors willing to remain in opposition and to mobilize executive oversight mechanisms. The article contributes to shed light on an aspect still little explored in the literature and to challenge the idea of a widespread subordination of city councilors to the mayors.
\end{abstract}

Keywords: mayor; local councilor; local council; executive branch; accountability

\title{
Resumen
}

Gobiernismo local: relación Ejecutivo-Legislativo en los municipios del estado de Minas Gerais

Ese artículo investiga el alcance del gobiernismo a nivel municipal, los incentivos para la alineación con el Ejecutivo y las estrategias que los alcaldes utilizan para construir su base de apoyo en la municipalidad. El análisis se basó en datos de una encuesta realizada con una muestra de concejales de los municipios de Minas Gerais. Las evidencias muestran que el gobiernismo está menos extendido de lo que uno podría suponer y que hay espacio para la acción independiente de los concejales. También revelan que hay una gran proporción de concejales dispuestos a permanecer en la oposición y movilizar mecanismos de control y supervisión ejecutiva. El artículo contribuye a 
arrojar luz sobre un aspecto aún poco explorado por la literatura sobre el tema y problematiza la idea de un gobiernismo generalizado a nivel municipal y de la subordinación de los concejos municipales a los alcaldes.

Palabras clave: alcalde; concejal; concejo municipal; gobiernismo; control parlamentario

\section{Résumé}

Gouvernisme locale: relation Exécutive-Législative dans les municipalités de l'état du Minas Gerais Cet article examine l'étendue du gouvernisme au niveau municipal, les incitations à l'alignement avec l'Exécutif et les stratégies que les maires utilisent pour renforcer leur base de soutien au sein du conseil municipal. L'analyse a été basée sur les données d'une enquête sans précédent menée auprès d'un échantillon de conseillers de Minas Gerais. Les preuves montrent que le gouvernisme est moins répandue qu'on ne pourrait le penser et qu'il y a place pour une action indépendante des conseillers. Ils révèlent également qu'une forte proportion de conseillers est disposée à rester dans l'opposition et à mobiliser des mécanismes de surveillance et de contrôle du pouvoir Exécutif. L'article contribue à éclairer un aspect encore peu exploré par la littérature sur le sujet et problématise l'idée d'un governisme généralisé au niveau municipal et de la subordination des conseillers municipaux aux maires.

Mots-clés: maire; conseiller municipal; mairie; gouvernisme; surveillance

Artigo submetido à publicação em 16 de janeiro de 2020. Versão final aprovada em 15 de janeiro de 2021.

Opinião Pública adota a licença Creative Commons CC-BY. 